IZA DP No. 9390

Stemming the Tide: What Have EU Countries

Done to Support Low-Wage Workers in an Era of Downward Wage Pressures?

Sarah Marchal

Ive Marx

September 2015 


\title{
Stemming the Tide: What Have EU Countries Done to Support Low-Wage Workers in an Era of Downward Wage Pressures?
}

\author{
Sarah Marchal \\ Herman Deleeck Centre for Social Policy, University of Antwerp \\ Ive Marx \\ Herman Deleeck Centre for Social Policy, University of Antwerp \\ and IZA
}

Discussion Paper No. 9390

September 2015

\author{
IZA \\ P.O. Box 7240 \\ 53072 Bonn \\ Germany \\ Phone: +49-228-3894-0 \\ Fax: +49-228-3894-180 \\ E-mail: iza@iza.org
}

Any opinions expressed here are those of the author(s) and not those of IZA. Research published in this series may include views on policy, but the institute itself takes no institutional policy positions. The IZA research network is committed to the IZA Guiding Principles of Research Integrity.

The Institute for the Study of Labor (IZA) in Bonn is a local and virtual international research center and a place of communication between science, politics and business. IZA is an independent nonprofit organization supported by Deutsche Post Foundation. The center is associated with the University of Bonn and offers a stimulating research environment through its international network, workshops and conferences, data service, project support, research visits and doctoral program. IZA engages in (i) original and internationally competitive research in all fields of labor economics, (ii) development of policy concepts, and (iii) dissemination of research results and concepts to the interested public.

IZA Discussion Papers often represent preliminary work and are circulated to encourage discussion. Citation of such a paper should account for its provisional character. A revised version may be available directly from the author. 
IZA Discussion Paper No. 9390

September 2015

\section{ABSTRACT}

\section{Stemming the Tide: What Have EU Countries Done to Support Low-Wage Workers in an Era of Downward Wage Pressures?*}

Governments across the EU have been striving to get more people into work while at the same time acknowledging that more needs to be done to 'make work pay'. Yet this drive comes at a time when structural economic shifts are putting pressure on wages, especially of less skilled workers. This article focuses on trends in minimum wages, income taxes, and work-related benefits within a selection of 16 EU countries, for the period 2001-2012, with three US states included as reference cases. We find evidence for eroding relative minimum wages in various EU countries, yet combined with catch-up growth in the new Member States. We also find that governments counteracted eroding minimum wages through direct income support measures, especially for lone parents. Most prevalent among these were substantial declines in income tax liabilities. More generally we see a trend unfolding towards a fiscalization of income support policies.

JEL Classification: $\quad 138$

Keywords: minimum wage, income support, fiscalization, lone parents

Corresponding author:

Ive Marx

Centre for Social Policy

University of Antwerp

St Jacobstraat 2

2000 Antwerpen

Belgium

E-mail: ive.marx@ua.ac.be

\footnotetext{
* The research for this paper has benefited from financial support by the European Union's Seventh Framework Programme (FP7/2012-2016) under grant agreement $\mathrm{n}^{\circ} 290613$ (ImPRovE: Poverty Reduction in Europe: Social Policy and Innovation; http://improve-research.eu). The authors would like to thank Tim Goedemé, Bea Cantillon, Lane Kenworthy, the participants to the Autumn Improve Meeting in Budapest, and the participants to the $22^{\text {nd }}$ FISS international conference in Hong Kong for their comments and suggestions. Sarah Marchal gratefully acknowledges a PhD scholarship from the Research Foundation Flanders. The authors are solely responsible for any remaining shortcomings and errors.
} 


\section{Table of contents}

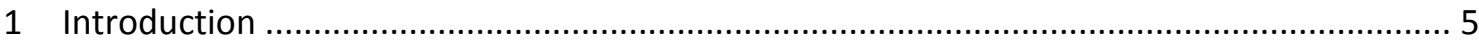

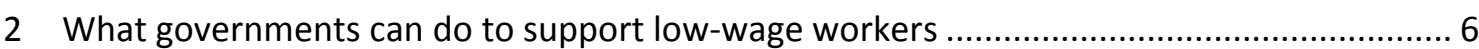

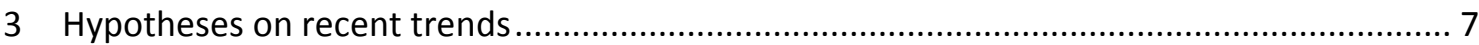

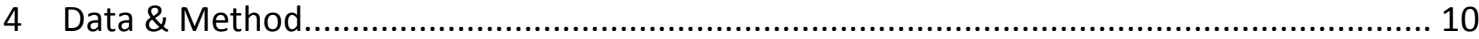

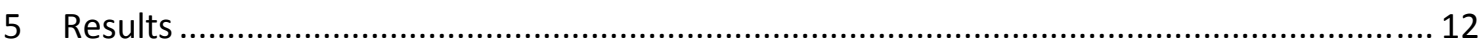

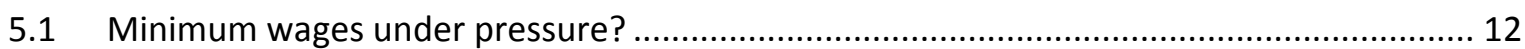

5.2 Do minimum wages protect against poverty? ................................................................. 17

5.3 Additional government support to boost the incomes of minimum wage workers? .......... 18

5.3.1 Overall trends in net income of minimum wage workers ...................................... 18

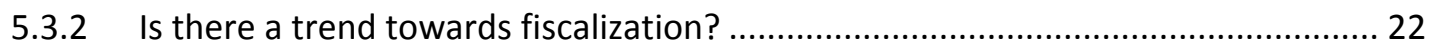

5.3.3 Are working lone parents deemed more deserving? ............................................. 24

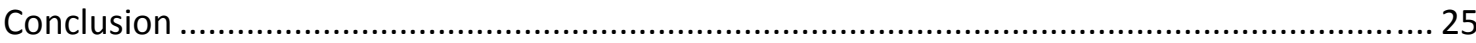

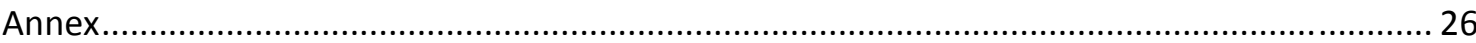

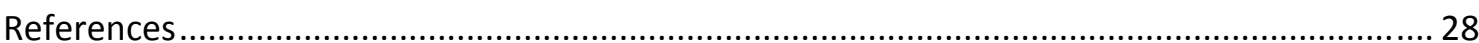




\section{Introduction}

We are living in an era in which intensifying international economic competition and skill-biased technological change are exerting downward pressures on the wages of workers in rich countries, especially on the wages of relatively low skilled workers. With continuing deindustrialisation, automation and outsourcing, many less skilled workers have come to rely on service sector jobs which cannot be readily outsourced or automated, but where productivity and thus wage gains are also achieved less easily. More workers for relatively fewer jobs may also mean that some people are willing to work for less, potentially driving down wages in that segment, unless minimum wages set a buffer. In addition, there may be increased competition from migrant workers in many countries. Whereas these changes impact on all rich countries, some of them may weigh more heavily within the common market of the European Union. Since the 2004 and 2007 enlargements, workers from the former communist countries of the EU have gradually but altogether rapidly gained free access to the old EU countries, where wages and working conditions tend to be far better than in their home countries, comparatively speaking. This (potential) migration may well be putting considerable pressure on those wages. That pressure need not only come from permanent migrants. Posted workers for example tend to undercut local wages by a wide margin.

Yet while wages may be under pressure, especially for the less skilled in the richest countries, in-work poverty has come front and centre as a policy concern, paradoxically at the same time that 'a job is the best protection against poverty' became a central tenet of EU policy (European Commission, 2011). Added to this is an increased concern for child poverty, as a significant number of children in poverty live in families where the full earning potential is already fulfilled, such as lone parent households, or families with low-educated parents (see e.g. Vandenbroucke \& Diris, 2014; Vandenbroucke \& Vinck, 2013 for Belgium). With in-work poverty rates close to ten per cent in the EU (and on the rise) (Eurostat, 2014), policy makers and international organizations proclaim the need to make efforts to increase take-home pay. Supporting low-income working households is furthermore necessary to lend credibility to the policy turn towards 'activation' and 'making work pay' (Weishaupt, 2011).

In this paper we assess whether years of growing concern about downward pressure on wages, inwork poverty and 'making work pay' are actually reflected in increasing policy efforts. We focus on trends in minimum wages, tax relief measures, and benefits in a period of continued European integration and activation reforms. We assess whether we find similar patterns within a selection of 16 EU countries, in the period 2001-2012. Three US states are included as reference cases, especially because the US is seen as a country where low pay is rife but also where much has been done to support low-paid workers. More specifically, we ask the questions i) whether increasing pressures on low wages have affected minimum wages, and ii) whether EU countries took measures to stem the tide for working low income families. Moreover, do we find evidence for similar policy instruments, and were similar groups targeted out for support? We focus here on fiscal vs. non-fiscal policy measures and lone parents vs. breadwinner couples. 


\section{What governments can do to support low-wage workers}

Governments have multiple options to support low income working households. Marx et al. (2013) distinguish between direct vs. indirect support (see Table 1), and incremental options (that build on existing arrangements) vs. options that would in most countries require the implementation of entirely new efforts. In this paper, we focus on direct income support measures: minimum wages, tax relief measures (through income taxes or social security contributions), and benefits, such as for instance child benefits or in-work benefits.

Table 1. The policy toolbox to support low-paid workers

\begin{tabular}{|c|c|c|}
\hline & Incremental options & New options \\
\hline $\begin{array}{l}\text { Direct } \\
\text { support }\end{array}$ & $\begin{array}{l}\text { - raising the minimum wage/ wage floors through } \\
\text { regulation } \\
\text { - (targeted) tax relief } \\
\text { - (targeted) reductions of employee social } \\
\text { security contributions } \\
\text { - (targeted) child benefits }\end{array}$ & $\begin{array}{l}\text { - negative income taxes } \\
\text { - (means-tested) in work benefits }\end{array}$ \\
\hline Indirect support & $\begin{array}{l}\text { - upskilling/training } \\
\text { - demand policies (subsidized employment, } \\
\text { wage cost subsidies) } \\
\text { - active labour market policies } \\
\text { - facilitating labour participation (e.g. child care) }\end{array}$ & $\begin{array}{l}\text { - Innovative demand oriented policies (e.g. service } \\
\text { cheques) } \\
-\quad \text { Innovative supply focused policies } \\
\text { (empowerment) }\end{array}$ \\
\hline
\end{tabular}

Source: (Marx, Horemans, et al., 2013)

The minimum wage is a particularly wide-spread policy tool. Yet a national minimum wage is no antipoverty tool per se. In fact, studies suggest that the anti-poverty impact of raising minimum wages would be quite limited, mainly due to the large spill-over effects to multi-earner families (Dolado, Felgueroso, \& Jimeno, 2000; Freeman, 1996; Marx, Vanhille, \& Verbist, 2012). Minimum wages are nonetheless useful as they contribute to a fairer wage distribution (International Labour Organization, 2008) and install an absolute wage floor that prevents other direct income support measures to be creamed off by employers. Nearly all EU Member States have a national statutory minimum wage (Marx, Marchal, \& Nolan, 2013). There are some exceptions, most importantly the Scandinavian countries, Austria, Italy and Germany. Yet in 2009, the Austrian social partners included in a national agreement a minimum wage that although not statutory, does cover the large majority of the labor force. Germany has introduced a national minimum wage in 2015. Finally, Belgium and Greece have a quasi-statutory minimum wage. Despite its international prevalence, large variation exists in minimum wage levels. Within the EU, the highest minimum wage (in Luxembourg) outranked the lowest (in Latvia) by a factor of 5 in purchasing power standards in 2012. This variation decreases substantially in relative terms, but substantial differences between the highest minimum wage (in France, at $48 \%$ of the average wage in 2012) and the lowest (the Spanish minimum wage at $29 \%$ ) remain. Also, the share of employees that works for a minimum wage differs largely among the EU countries. Ryckx and Kampelmann (2012) use the EU-SILC to comparably estimate the share of minimum wage workers in 8 EU Member States in 2007. They find substantial variation, with only $3.8 \%$ of the workforce working for a minimum wage in Spain, to $11.5 \%$ in Hungary. Part of this variation is explained by the different level of minimum wages. In addition, in some countries, such as Belgium, sectoral agreements lay an entire additional structure of minimum wage protections above this national income floor.

The other policy tools listed in Marx et al. (2013) all have a more direct cost to the government. They distinguish between incremental options (augmentations or modifications of existing policies) and 
innovative options that radically depart from or complement existing policies. Targeted tax relief, reduction of social insurance contributions and targeted child benefits fall within the first category. The progressivity of most European tax systems in combination with tax allowances for children and dependent partners effectively brings tax liabilities to zero for larger low-income families. In addition, some countries have installed tax allowances for costs related to working, or even tax allowances for low wage workers. In contrast, all workers generally pay an equal percentage of their wage as social security contributions in order to be insured against social risks such as illness, unemployment etc. As insurances go, this is already quite a beneficial arrangement for low wage workers, as they generally have higher risks, and are protected by minimum benefits in case of incurring a risk (Cantillon $\&$ Van Mechelen, 2014). Yet in most countries it would be possible to further lower their required contributions in order to safeguard a decent net income from work. Such arrangements are as yet quite rare in the EU (Marx, Marchal, et al., 2013). Finally, in many countries low income working families will be eligible for one or more different benefits. The most common income support is child benefits. All EU Member States have either universal or means-tested child benefits, or both (Van Lancker \& Van Mechelen, forthcoming; Van Mechelen \& Bradshaw, 2013). Other quite common costrelated income support measures are housing allowances (and, more rarely, heating allowances). Finally, Marx et al. (2013) point to the (mainly Anglo-Saxon) innovative examples of refundable tax credits and in-work subsidies. Some overlap exists between these different categories. For instance, in-work subsidies may take the form of employment-conditional refundable tax credits, or employment-conditional (means-tested) child benefits. Kenworthy (forthcoming) focuses more closely on in-work subsidies (or employment-conditional earnings subsidies, as he calls them). These income support measures have the dual objective of both raising employment levels and reducing poverty. It is however by no means self-evident to simultaneously reach both goals through the same policy measure. Kenworthy (forthcoming) defines employment-conditional earnings subsidies as income support measures where eligibility requires employment, and identifies a wide range of dimensions on which they may vary. The three most important types he identifies are i) large refundable tax credits or cash transfers with phase-in and phase-out ranges; ii) a large reduction in employee payroll tax payments and labor costs, and iii) large tax credit or cash transfer with no phase-out. In line with the dual purpose of in-work subsidies, it may perhaps be equally valid to focus on i) whether benefits are targeted at the individual or at the household (in line with a focus on individual work incentives or poverty protection) and ii) are means-tested or not (i.e. whether they have a phase-out range, and related issues on how certain types of income are disregarded). In line with recent trends in France and the UK to integrate in-work benefits in broader income protection schemes through important earnings disregards, it might furthermore be useful to not solely look at employment-conditional benefits but broaden the scope to all possible income support measures, and clearly distinguish whether they are targeted to workers, other categories, or the entire working age population.

\section{Hypotheses on recent trends}

Over the last decades, European countries have become ever more integrated. This was part of a global trend towards ever more integrated economies and societies (Jensen, 2010). In addition, the EU took an active role in this, through its establishment of a single market. Whereas this was initially an integration movement between relatively similar nations, the more recent enlargements towards the East of Europe widened internal variation between the various EU Member States (Kvist, 2004). 
This ongoing process of economic integration of European labour markets has led many to expect increasing pressures on labour market rigidities and income protection measures (Kvist, 2004; Paetzold \& Van Vliet, 2012; Scharpf, 2002; Sinn, 2002; Van Vliet, Caminada, \& Goudswaard, 2010). Indeed, in guaranteeing a free market of goods, services, capital and persons, the EU boosts competition between (richer and poorer) Member States. Moreover, the European Court of Justice has often ruled in favour of this free market as opposed to safeguarding more protectionist acquired rights (e.g. the Viking and Laval arrests; see Malmberg, 2010; Verschueren, 2015). But also fears (imaginary or not) that migrants from poorer Member States will move to richer Member States not solely for improving their labour market prospects, but also attracted by their safety nets for those out of work (and recently, in the UK, even by their in-work benefits) are relevant in this regard. Minimum wages can be seen as one of these acquired social rights. Moreover, they generally cater for the specific target group of low-skilled and/or young, starting workers, whose jobs may be especially likely to suffer from increasing global competition (Ryckx \& Kampelmann, 2012). Whether or not this is really the case might not actually matter, as fears for pricing oneself out of the market may be enough to forego increases in minimum wages ${ }^{1}$.

It is then feared that governments might enter into an underbidding strategy (a "race to the bottom"), making their country relatively more attractive to investment and less attractive to migrating EU citizens. Up till now, this has mainly been researched for social benefits (Draxler \& Van Vliet, 2010; Montanari, Nelson, \& Palme, 2008; Van Mechelen \& Marchal, 2013) and broader labour market rigidities (Erhel \& Zajdela, 2004; McBride \& Williams, 2001; Skedinger, 2010), rather than for the specific case of minimum wages. Evidence resulting from this literature remains rather inconclusive.

\section{H 1: We expect a downward convergence of minimum wages in the single market of the EU.}

At the same time, a number of developments have raised attention to net take-home pay of low wage workers and low income families. For one, despite improving employment records before the crisis in most EU Member States (Van Rie \& Marx, 2012), no real progress was made towards the EU's goal of fighting poverty (Cantillon \& Vandenbroucke, 2014). The growth in employment mainly benefited households where one adult was already in work, rather than promoting labour attachment of marginalized groups (Corluy \& Vandenbroucke, 2014). In addition, a job does not always suffice to lift someone out of poverty, especially not so when there are a number of persons to support on that sole income (Marx \& Nolan, 2014).

As social policy has come to rest more and more on principles of activation, fighting in-work poverty has become crucial in yet another perspective. International organizations and scholars of activation policies alike see efforts to increase take-home pay as indispensable elements of an activation strategy (European Commission, 2008a; Immervoll, 2012; Weishaupt, 2011). For one, it helps to ensure that persons actually have a substantial financial incentive to take up employment. In addition, making sure people in work do escape poverty is a cornerstone of a believable activation policy.

\footnotetext{
${ }^{1}$ A counterargument to this expectation of downward pressures and convergence posits that precisely because of this increased insecurity, the local political demand for social protection will rise. Combined with the rising prosperity in the poorer EU Member States, a number of authors argue against this race to the bottom argument, and some even expect an upward convergence through catch-up growth (e.g. Paetzold, 2012).
} 
Hence, even though the "race to the bottom argument" might also pertain to net minimum wages (for instance, current public debate in the UK centres on whether or not EU-migrants working in the UK should also be able to qualify for in-work benefits (Gaffney, 2014)), the argument is far less clear-cut. Indeed, policy makers have strong incentives to target additional support to low income working families, and the policy instruments to do so. Focusing on take home pay has the benefit that it at the same time increases financial incentives and makes work more attractive, while, contrary to raising minimum wages, having a more limited impact on the labour market. On the other hand, it is a relatively expensive policy option. Yet, it has been actively propagated by international organizations and scholars alike (Cantillon, Collado, \& Van Mechelen, forthcoming; European Commission, 2008b; Immervoll, 2012; OECD, 2009).

H2: Policy makers targeted additional effort towards low income working families.

Within the context of integrating social policy and social policy objectives of EU Member States, two related questions seem relevant. More precisely: were there particular types of support measures preferred? Did some family types benefit more from this additional support than others?

International organizations and scholars alike have been particularly interested in the potential of tax benefits to target support to low income families (Immervoll, 2007; OECD, 2005). Using the tax system to support particular families is no new notion. Their progressive design and the often large tax allowances for children or other dependent family members are only some examples of how tax systems seek to reinforce social policy (Adema, 1997). A particular type of tax benefit is a tax credit, a tax benefit that is subtracted from the final tax liability. To the extent that these tax credits are refundable, they may even result in a net benefit to families with low tax liabilities. The Anglo-Saxon countries were quite early in taking this aspect of taxation one step further, installing (initially relatively minor) tax credits already in the 1970s and 1980s. The two most well-known examples, the Earned Income Tax Credit (US) and the Working Tax Credit (UK), target low income working families, with more generous rates for families with children. Eventually, additional tax credits got introduced, for children and child care costs, an example also followed by other countries. Nonetheless, there are doubts regarding the easy transferability of this policy instrument towards other welfare states (Marx et al., 2012).

Looking at child support, and focusing on the period since 1960, Ferrarini, Nelson and Höög (2013) find evidence for a fiscalization of child support in a significant number of Western countries. They argue that child support tends to be more and more organized through a combination of tax credits, tax allowances and benefits, rather than through benefits solely. Given the ample policy attention the Anglo-Saxon working tax credits have raised, it can be expected that this trend is not solely confined to child support, but also includes support towards low income (working) families more generally.

H2a: Additional support towards low income working families was mainly provided through the tax system.

As stated above, part of the reason why we would not expect net incomes to exhibit a downward convergence pattern stems from the increasing focus on activation and related make-work pay policies. International organizations have repeatedly called for removing disincentives emanating from the tax benefit system, and to implement policies that facilitate the combination of work and family life (e.g. European Commission, 2008b). 
This activation turn aligns with a broader shift towards a new organizing principle of Western welfare states. Specifically for the EU, Member States are moving away from the male breadwinner model as the traditional underpinning of their welfare state policies (a basis that is especially apparent in the continental and Southern European states) (Bradshaw \& Hatland, 2006), and moving forward to an adult worker model, where social policies will supposedly be oriented around the assumption that anyone who can will work² (Annesley, 2007; Daly, 2011; Knijn, Martin, \& Millar, 2007). This should not necessarily mean a withdrawal of the welfare state, but rather a reorganization of policies towards active labour market policies, higher wages (and benefits) and child care support. Skevik (2006) for instance, discusses various policy measures in Western and Scandinavian countries in the 1990s that focused on helping lone parents to work their way out of poverty, as a target group that was previously considered to deserve out-of-work benefits based on their single status alone. Not all countries introduced this kind of measures in the 1990s, and those that did showed quite some variation, with a single focus on child care support to outright income supplementation.

A new target group of in-work support then comes into focus, i.e. families who, despite their full-time (or substantial) involvement in the labour market, do not succeed to escape poverty. An obvious example is a working lone parent. Indeed, child poverty rates indicate that poor children with at least one working parent disproportionally often live in lone parent households (Vandenbroucke \& Vinck, 2013). A single low wage no longer suffices to protect a family against poverty. In the case of a working lone parent, it is obvious that further increasing the labour market attachment of the household cannot provide solace. We may therefore suspect a move towards providing in-work support to lone parent families relative to breadwinner families.

H2b: lone parents gained relatively more support than breadwinner couples did.

\section{Data \& Method}

This paper assesses trends in minimum wages and related income components in a cross-nationally comparable way by using standard simulations. Standard simulations are calculations of the net disposable income and its components for a typical model family, according to the applicable tax benefit rules. The characteristics of the model family are defined by the researcher and depend on the research question. The simulations used in this paper are taken from the expert-sourced CSB MIPI dataset. Experts perform the standard simulations based on a uniform set of assumptions that aim to maximize cross-national and cross-temporal comparability, as well as to gauge minimum income situations.

In this paper, we use the simulations of net disposable income of a 35-year old single and couple, either childless or with two children aged 7 and 14 . The model families are assumed to have no savings or income other than the earned wage and income supplements provided by the tax benefit scheme. In each family, one adult works full-time, and is remunerated at the minimum wage. If present, the

\footnotetext{
${ }^{2}$ Annesley (2007) states that this is the main innovation of the Lisbon agenda. Whereas activation has always been present in some form in the European welfare states, the focus used to be on activating the most productive workers. The main change in the reinvigorated interest in activation in the past decades (as made explicit in the Lisbon agenda) is that the group of people considered in need of activation has broadened to more and also less productive workers. Spouses of earners and lone parents have become viable target groups of activation.
} 
second adult in the household is assumed to be inactive. The wage is the national minimum wage, in full time employment. ${ }^{3}$ Moreover, families are assumed to be tenants, and to pay a rent equal to $2 / 3$ of median rent, in the social or private rent sector (in line with the most common rental sector in each country). In some countries, the $2 / 3$ median rent scenario was replaced by an assumption of either costless housing (as this is more representative for very low income cases in some Eastern European countries), or $20 \%$ of the average wage (in France). The simulations assess the situation for June 2001 and January 2012. As the model family type is defined in the same way in all countries, results are comparable and only indicate genuine policy changes rather than labour market or demographic changes.

A drawback of standard simulations is that the results are solely based on highly stylized family types. These family types are not necessarily as common in each country under observation. For instance, the share of tenants is extremely low in a number of Eastern European countries. Related to this observation is the issue of housing costs. Housing costs are an important determining factor of the income of families. This is not solely through the importance of net income after housing costs to assess a family's real disposable income, but also because in most countries the level of housing allowances is based on the actual housing costs faced. Higher or low housing costs may therefore effectively overor underestimate the level of the awarded housing allowances (see Van Mechelen, Marchal, Goedemé, Marx, \& Cantillon, 2011 for a discussion of the main advantages and limitations of CSB MIPI specifically). In this paper our focus rests however with trends over time, rather than with the actual level of net income packages and housing allowances. Unfortunately, for some countries housing costs assumptions are not comparable over time. As a consequence, trends reflect changes in net income excluding possible housing allowances in the United Kingdom. For the countries where housing allowances are included, it is important to remember that they reflect the combined effect of policy changes and trends in empirical housing costs, and that it is difficult to disentangle both. Net disposable income packages may also include top-ups from the social assistance scheme. Especially for couples, whether or not such a top-up is awarded may depend on the job search behaviour of the inactive spouse. The importance of this consideration may have shifted over time.

Trends in minimum wages and their related net disposable income are assessed against purchasing power trends (Harmonized Indices of Consumer Prices and Purchasing Power Parities from Eurostat, 2014), and median equivalent household income (from Eurostat, 2014). In addition, the robustness of trends in minimum wages is assessed through the use of time series data of monthly minimum wages on top of trends in minimum wages for a full-time working 35-year old in June 2001, to assess the impact of different reference data, working hours and experience related top-ups in some countries.

Box 1 below lists the measures used throughout the paper.

\footnotetext{
${ }^{3}$ Please note that a widely accepted definition of full-time employment does not exist. The number of hours required in a full-time job differs between sectors, and even more so between countries. The simulations assume full-time employment for each country, in line with national regulations. Where these may be lacking, we follow the national expert's judgment.
} 
Coefficient of variation: a measure to assess the variation on a specific indicator across a group of countries. It divides the standard deviation by the average value of the indicator.

Child income tax benefit: the difference in income taxes paid by a model couple (or single) with children with those paid by the same model couple (or single) without children. It acts as a measure of the tax advantage awarded solely because of the presence of children in the household. We track trends in the relative share of the child income tax benefit in total child effort to gauge changes in the importance of fiscal benefits. Please note that this is only a very crude measure of fiscalization (it only compares families with and without children, disregarding the fact that families without children may also be targeted by fiscal support). Hence, we also include changes in income tax rates to assess changes in the importance of taxes over time. An additional caveat relates to the classification of certain income measures. Despite their name, child tax credits are in some countries very much alike (means-tested or universal) child benefits. We follow the national respondent's judgment on the classification of support measures.

Total child effort: the difference in net disposable income of a model couple (or single) with children with that of the same model couple (or single) without children. It acts as a measure of the support awarded solely because of the presence of children in the household.

Total net support: the difference between the net income and the minimum wage of a model family (or, put differently, the sum of all benefits minus taxes and social insurance contributions). We track trends in relative net support towards lone parents vs. couples to assess whether support has been directed more towards lone parent families as compared to breadwinner couples with children. A similar approach was used by Van Lancker, Ghysels and Cantillon (forthcoming).

\section{Results}

\subsection{Minimum wages under pressure?}

A first hypothesis we seek to test in this paper is whether minimum wages are under pressure, and if so, whether this has led to a downward convergence of minimum wage within the EU. In Figure 1 we show minimum wage trends from June 2001 to January 2012 for the countries included in our sample. Countries are ranked according to the 2001 minimum wage level, in purchasing power parities (panel A) and relative to the average wage (panel B). Figure 1 does indeed show stagnating minimum wages in countries where these were initially rather high, both in real terms as relative to average wages.

Clearly, minimum wages have not been able to keep up with average wages in Belgium, the Czech Republic, France ${ }^{4}$ and Italy ${ }^{5}$. Figure 1 furthermore shows decreases for Lithuania and Romania. At the start of the period under observation, both countries still experienced large hikes in minimum wages,

\footnotetext{
${ }^{4}$ The French trends reflect the reduction in legal working time in full-time employment from 39 hours per week in 2001 to 35 hours per week in 2012.

${ }^{5}$ Italy does not have an actual minimum wage. Throughout this paper, we use the sectoral minimum wage in the low paid leather and fur sector as an approximation of the absolute wage floor.
} 
average wages and inflation rates. The results for these countries are therefore influenced to some extent by presenting the June 2001 minimum wage relative to the annual average wage.

Trends are even more worrisome relative to the median equivalent income (see figure 3). Also here, minimum wages decreased more often in countries where they were relatively speaking rather high to begin with. Taking the median equivalent income as proxy for the average living standard in a country, we find that minimum wages have not been able to keep up with living standards in Belgium, the Czech Republic, Estonia, France, Italy, Lithuania and Poland (and Portugal before the onset of the crisis), and this despite real increases in all countries but Belgium and Italy. On the other hand, relative minimum wages increased substantially in Hungary, Slovenia and the UK. Even though minimum wages are not subject to statutory indexation in both Hungary and the United Kingdom, tripartite negotiations (in Hungary) and the Low Pay Commission (in the UK) have issued relatively large increases over the past decade. In addition, in Hungary and Slovenia, minimum wages were raised substantially in the period 2010-2012. In Hungary, the increase of the minimum wage had to counteract the abolishment of the tax credit for low wage earners. In Slovenia, the 2010 minimum wage act increased the minimum wage by $30 \%$. After nearly 10 years, the US minimum wage was raised in three instalments from 2007 to 2009 through the 2007 Fair Minimum Wage Act. 
Figure 1. Trends in minimum wages, 2001-2012

Panel A. Real trends in purchasing power parities

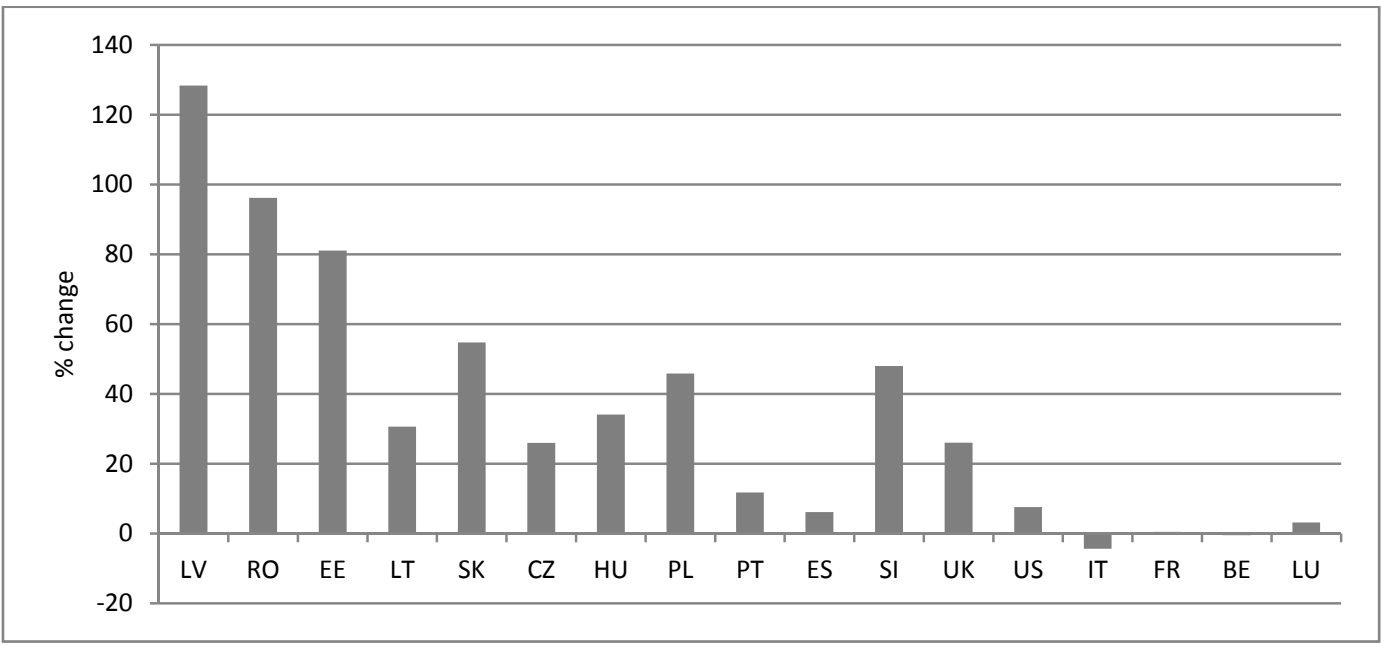

Panel B: Trends relative to average wages

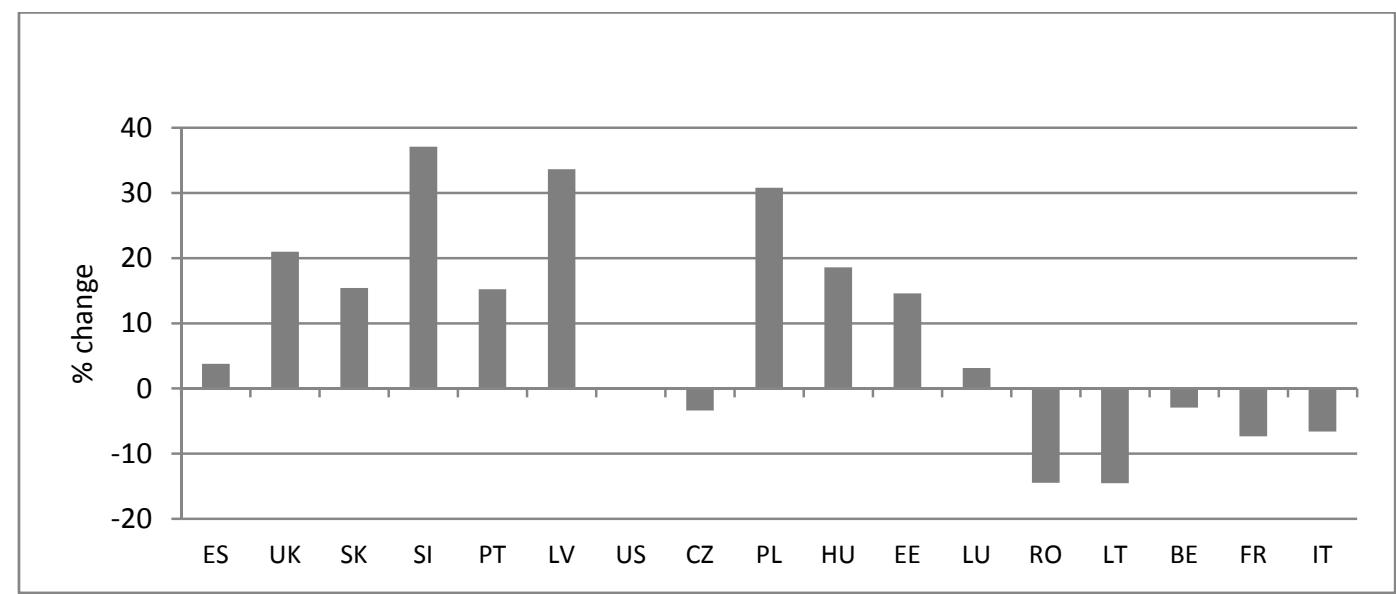

Note: countries are ranked according to the minimum wage level in 2001 in purchasing power parities, or relative to the average wage. Trends 2001-2012 are equal for the three US states included (Nebraska, New Jersey, Texas). Simulated minimum wage for a 35-year old full-time employee, in June 2001 and January 2012. ES: trends 2001-2009; IT: proxy for the wage floor.

Source: MIPI 3/2013 (Van Mechelen et al., 2011); PPP, HICP from Eurostat (2015), average wages from OECD (2015)

In Figure 2, we assess whether these different trends translated into less variation in minimum wage levels across countries. For minimum wages in purchasing power terms, this is evidently the case. The dotted lines in Panel A of Figure 2 show the coefficient of variation for the minimum wage in purchasing power terms across our sample of countries (both including and excluding the US, and separately for the old and new EU Member States with statutory minimum wages for which we have data). Within the EU countries, the coefficient of variation decreased substantially from 0,72 to 0,55 . This was coupled to a very substantial increase of minimum wages in real terms, on average by $39 \%$. These trends are similar when we include the US federal minimum wage in our assessment. Indeed, they are driven by the substantial real increase of minimum wages in the new EU Member States, on average by $66 \%$, in contrast to the far more modest real increase of $8 \%$ in the old EU Member States. Note that 
we look here at time series data (instead of the minimum wage employed in the standard simulations), as this allows us to both include a larger group of countries and to assess the robustness of our findings to slightly different underlying assumptions (see data section).

Relative to average wages, the variation within this group of countries is far more limited. In addition, the coefficient of variation shows only a slight decrease over the entire period. This is the case for both Western and Eastern European countries. With the exception of Bulgaria, the inclusion of individual countries does not affect the patterns apparent from figure 3 . The stark increase in the relative minimum wage in 2005 in this country is responsible for the sizeable bump in 2005. For the Eastern European countries, the slight convergence is mainly driven by the combination of Estonia, Lithuania and Romania. Yet, it is quite difficult to make the case that this is, in effect, an example of downward convergence. The average minimum wage has remained fairly stable, and even increased somewhat. On the other hand, there is no denying that minimum wages have decreased in relative terms in a substantial number of countries. In some countries, these decreases even were fairly substantial, such as Lithuania. Yet there have been important exceptions, such as Hungary, Slovenia and the United Kingdom. Rather, it seems to point towards a catch-up growth of countries where minimum wages were initially low, combined with limited downward trends in the remaining countries. 
Figure 2. Trends in variation of minimum wage levels, 2001-2012

Panel A. In purchasing power terms

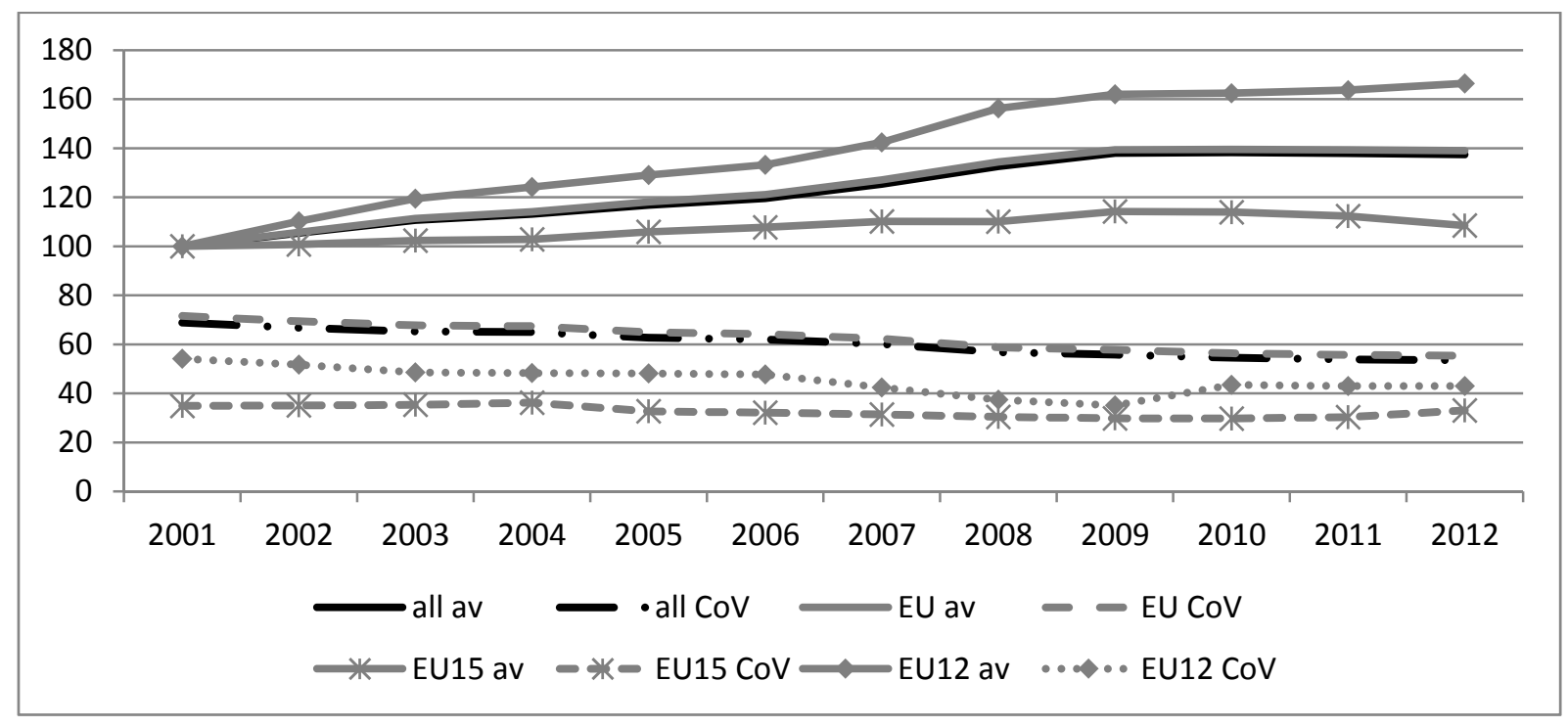

Panel B. Relative to average wages

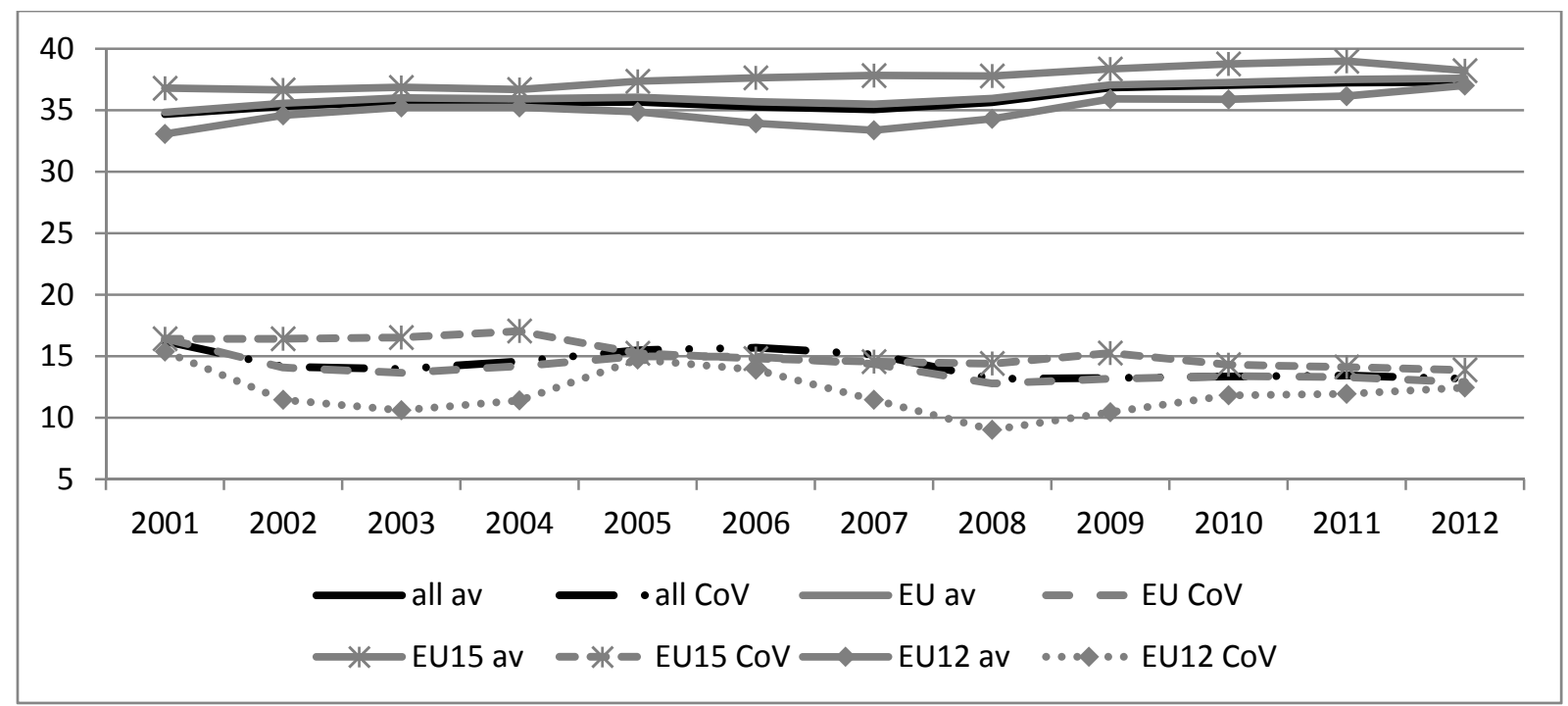

Note: all: EU + US federal minimum wage; EU: N=19 (BE, BG, CZ, EE, EL, ES, FR, HU, IE, LT, LU, LV, NL, PL, PT, RO, SI, SK, UK), EU15: N=9 (BE, EL, ES, FR, IE, LU, NL, PT, UK), EU12: N=10 (BG, CZ, EE, HU, LT, LV, PL, RO, SI, SK). Av: average; CoV: coefficient of variation. Average in panel A refers to the average real trend with 2001 = 100; variation in panel A refers to the variation of the minimum wage level in purchasing power parities. Average in panel B refers to the average minimum wage as a percentage of the average wage.

Source: CSB MIPI Version 3/2013 (Van Mechelen et al., 2011); average wages (OECD, 2015); PPP and HICP (Eurostat, 2015) 


\subsection{Do minimum wages protect against poverty?}

In the remainder of this paper, we focus on the potential of minimum wages to protect against poverty. Figure 3 therefore shows the trends in minimum wages relative to $60 \%$ of the national median equivalent household income, the EU at-risk-of-poverty threshold. Trends are expressed in percentage points, relative to the poverty threshold for a lone parent with two children, according to the modified OECD equivalence scale. Figure 3 confirms the picture presented in Figure 1, of minimum wages under pressure in a number of countries where they were initially relatively high ${ }^{6}$. The average minimum wage relative to the poverty threshold for a lone parent with two children remained around $65 \%$ in the period under observation. This is a far cry from the level that a lone parent family with two children would actually need to escape the risk of poverty. It is clear that the minimum wage does not suffice when more people in the household depend on it, and this has been the case for quite some time now. The question than arises whether and how governments have stepped in to support minimum wage earners over the past decade.

Figure 3. Percentage point change in minimum wage relative to poverty threshold, 2001-2012, ranked by 2001 level

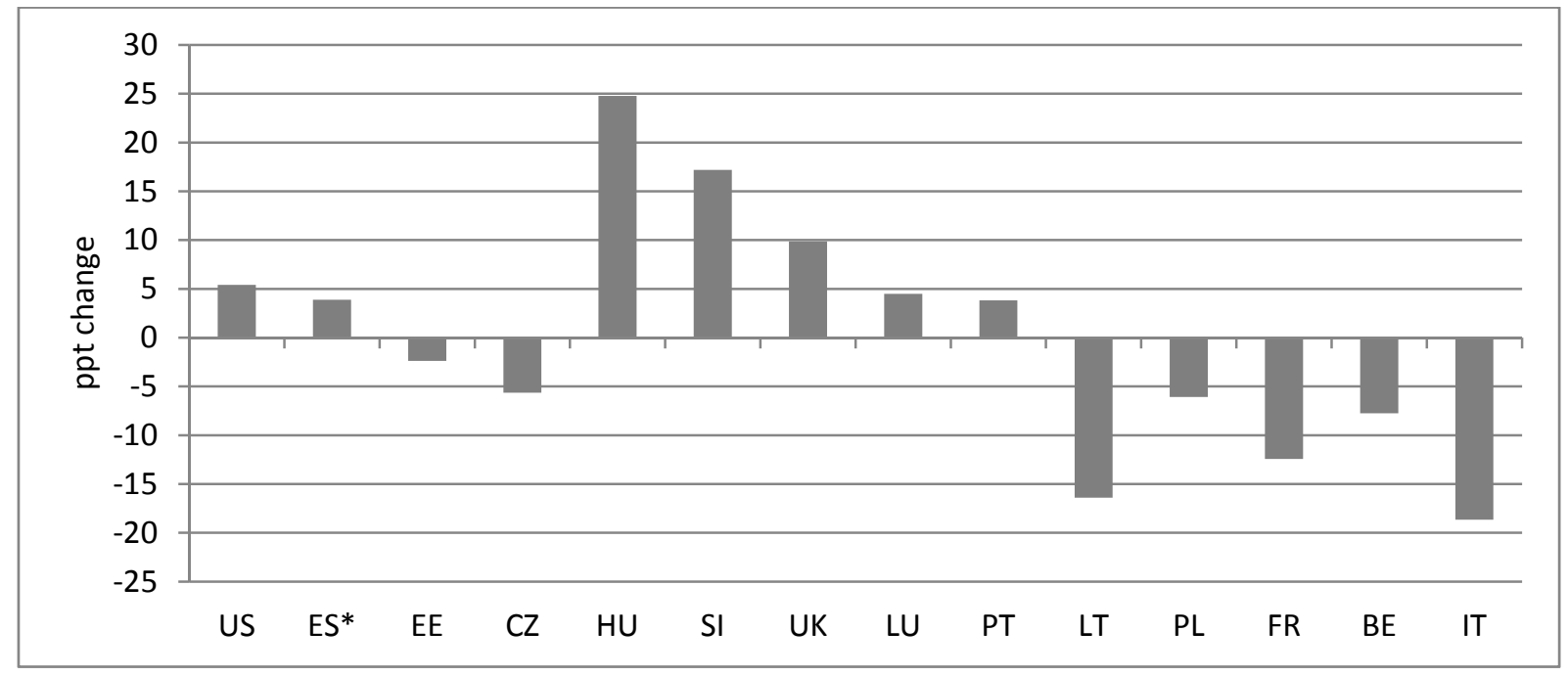

Note: Percentage point changes based on the poverty threshold for a single person household. See note to figure 1.

Source: CSB MIPI Version 3/2013 (Van Mechelen et al., 2011), Eurostat (2014)

\footnotetext{
${ }^{6}$ An important reservation applies: the relative minimum wage is calculated against the median equivalent household income from Eurostat, based on respectively the ECHP (in 2001) and EU-SILC (in 2009 and 2012) household surveys. The resulting poverty thresholds used here are therefore not necessarily fully comparable over time.
} 


\subsection{Additional government support to boost the incomes of minimum wage workers?}

\subsubsection{Overall trends in net income of minimum wage workers}

Figure 4 compares percentage point changes in minimum wages and simulated net disposable income at a full time minimum wage relative to the poverty threshold, for different households: a single, a breadwinner couple, a breadwinner couple with two children and a lone parent with two children. In the majority of countries, trends in net incomes were more favourable than trends in minimum wages. Estonia and Hungary are the sole countries where trends in net incomes were consistently worse than trends in minimum wages ${ }^{7}$. In addition, there are large differences between different family types.

These diverging trends between gross vs. net minimum wages, and between family types, clearly indicate that changes have happened to income components other than minimum wages. In this contribution, we assess changes to direct income support: taxes, social insurance contributions, child benefits, and social assistance top-ups ${ }^{8}$. In Figure 4, we group trends in these income components under taxes (income taxes, local taxes and social insurance contributions) and benefits (child benefits, social assistance top-ups, and housing allowances) for the sake of presentation. The discussion below focuses on trends in the underlying income components (shown in Tables 3 to 6 in appendix).

Over the past few decades, some of these income components have changed quite substantially. Most in particular, tax liabilities have declined sharply. In all countries but Poland, France and the US, changes to income taxes had a positive effect on the net disposable income of minimum wage earners without children. Benefiting from child tax allowances and tax credits, tax liabilities for low wage families with children were already very low to begin with (see Table 5 and 6 in annex), but even for these family types, further tax liability decreases were common. By 2012, tax rates for families with children in most countries approached zero. Lithuania, the only country with a substantial tax liability for families with children to begin with (at $24 \%$ for a couple with two children in 2001), decreased the tax rate to a mere percent of the minimum wage by 2012. The Czech Republic and Slovakia both introduced a substantial child tax credit, following the American and British example. Local taxes are generally insignificant.

Social insurance contributions are generally the same for all family types (see annex), in line with their individual, contributory logic. The one exception is the Czech Republic, where social insurance contributions have to be paid for the voluntary inactive spouse. Figure 1 shows some changes in contribution rates. Generally, these changes remained quite limited. A number of Eastern European countries (such as Estonia) added insurance categories. Belgium on the other hand, introduced a substantial social insurance rebate for low wage workers, de Werkbonus. A similar measure exists in the Netherlands.

Child benefits are an important income component for families with children. The only country of our sample that did not provide child benefits was Lithuania in 2001. By 2009, it had however introduced a universal child benefit. Budgetary concerns led the Lithuanian government to make it a means-

\footnotetext{
${ }^{7}$ Similar results were found for Greece and Ireland - not shown here due to changing assumptions on minimum wages.

${ }^{8}$ Changes in housing allowances are included in both the graphs in Figure 4, as in the tables in appendix. However, as they are driven by both trends in housing costs and policy changes, we will not focus on these in our discussion.
} 
tested benefit by 2012, yet families relying on a single minimum wage remained eligible. In most other countries however, child benefits either remained fairly stable or decreased. In the Czech Republic and Slovakia, this is related to the introduction of a child tax credit (included under income taxes). A particularly stark decrease occurred in Estonia. In reaction to the crisis, the government issued a number of austerity measures, including the abolishment of the school allowance in 2009. In Belgium and Poland, child benefits for lone parent families became more generous.

Trends in social assistance top-ups are difficult to interpret. Social assistance is a means-tested, residual benefit. It often takes all possible income sources into account (in some countries child benefits or housing allowances may be disregarded). The extent to which income from work is taken into account varies substantially (e.g. in full in Estonia, whereas in France a disregard of $62 \%$ applies). The changing impact of social assistance top-ups on net disposable income therefore not necessarily reflects policy changes with regard to social assistance, but may well reflect the changes to the other income components discussed above. The substantial rise in social assistance for French minimum wage families however clearly reflects an important policy change. The $2009 \mathrm{rSa}$ reform installed a substantial earnings disregard, in order to ensure that even low paid part time jobs provide a financial incentive to take up work. In Portugal, the increase in social assistance is only relevant for lone parents. A breadwinner couple (with a voluntarily inactive spouse) is indeed not eligible as long as the spouse is not willing to actively search for work. Moreover, this social assistance top-up decreased from 2009 to 2012 (see annex). The 2010 reform of the Portuguese social assistance scheme changed the underlying equivalence scales of the benefits, leading to overall less generous benefits (Rodrigues, 2012). Also for the Czech Republic, the substantial decrease in social assistance payments is the result of a far-reaching reform in 2007 that recalibrated the relative importance of housing allowances vs. social assistance. 
Figure 4. Percentage point changes to the net income package and income components of a one-earner family, employed at minimum wage, 2001-2012

Panel A. Single person household

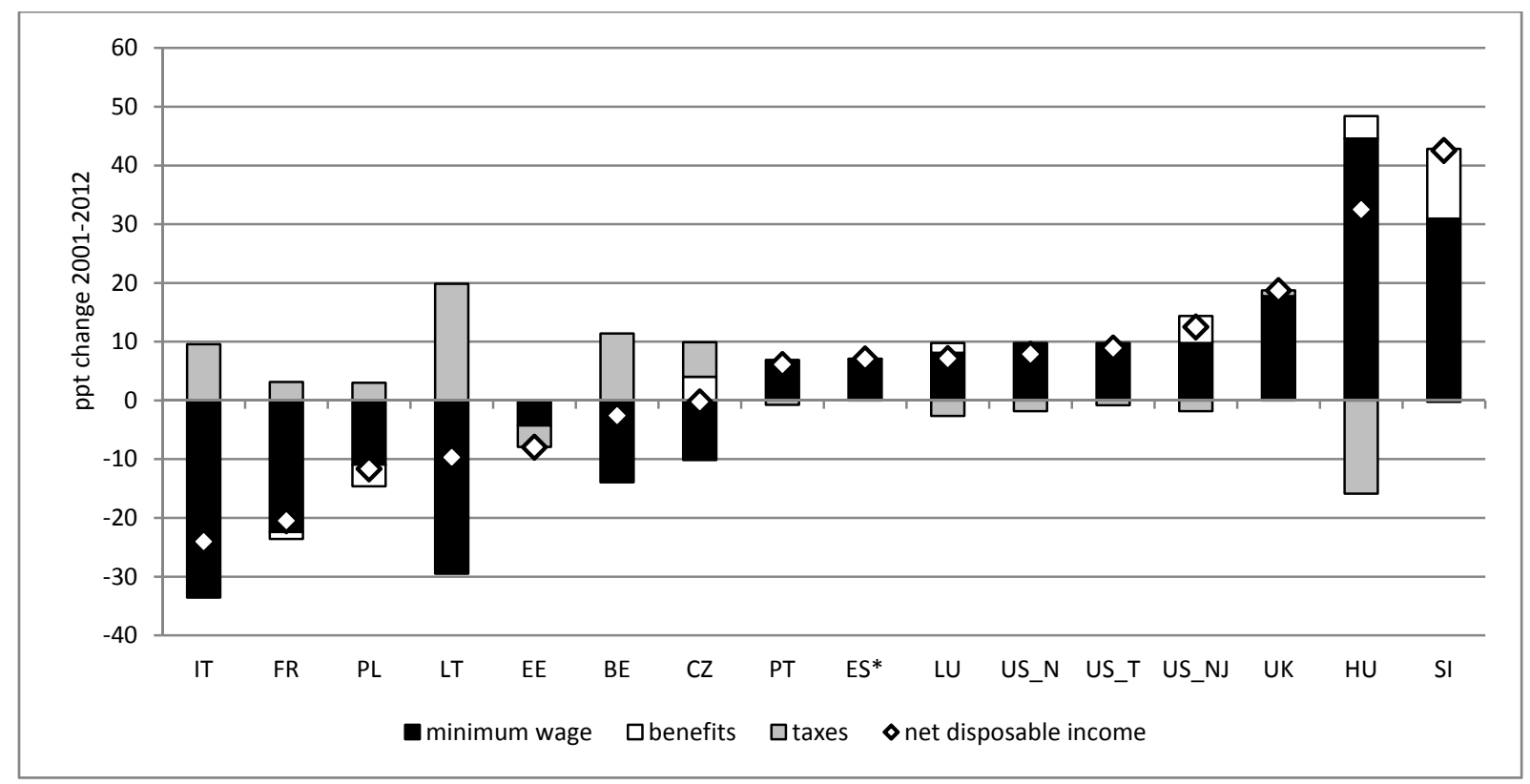

Panel B. Couple household

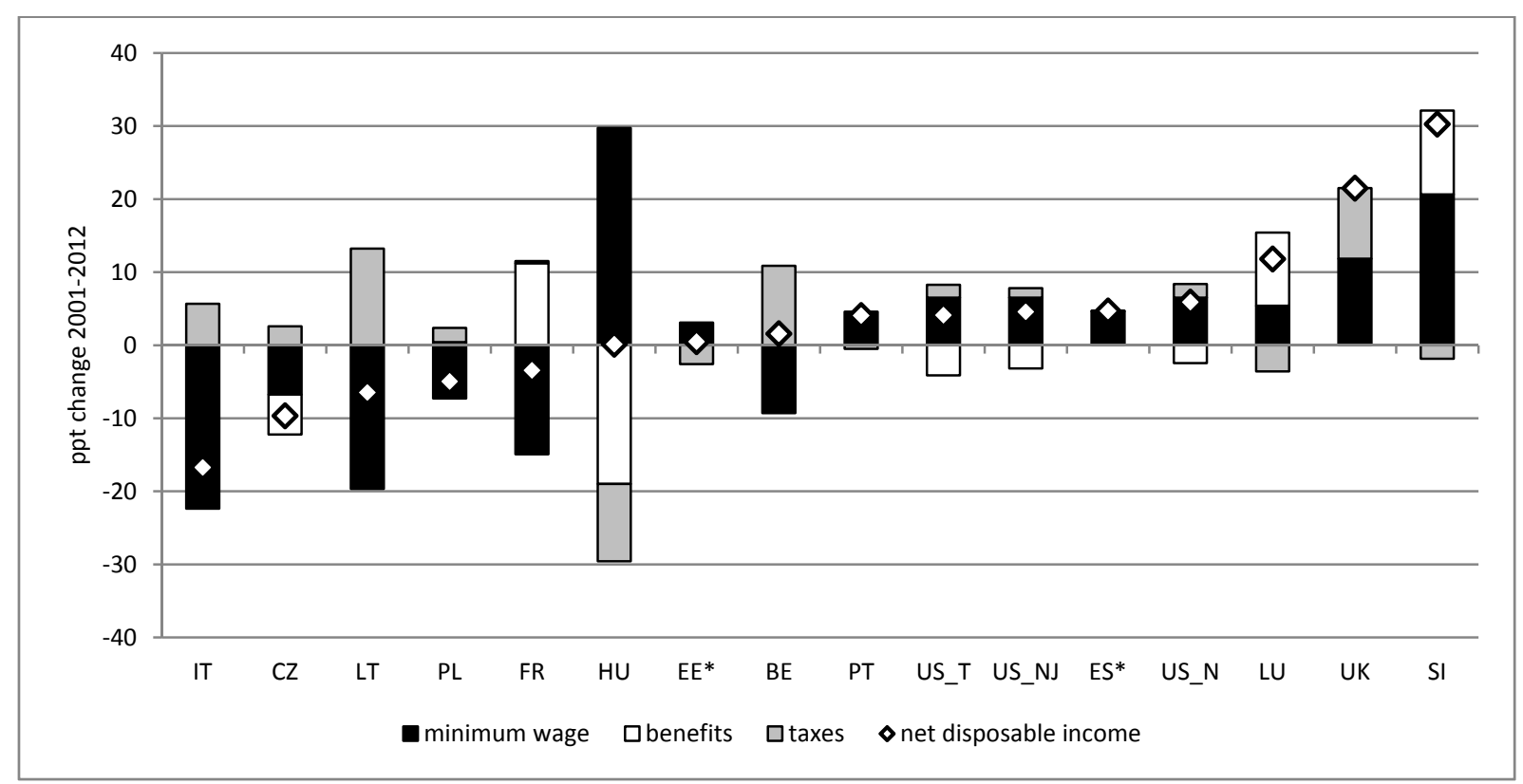


Figure 4 - continued

Panel C. Couple with two children, aged 7 and 14

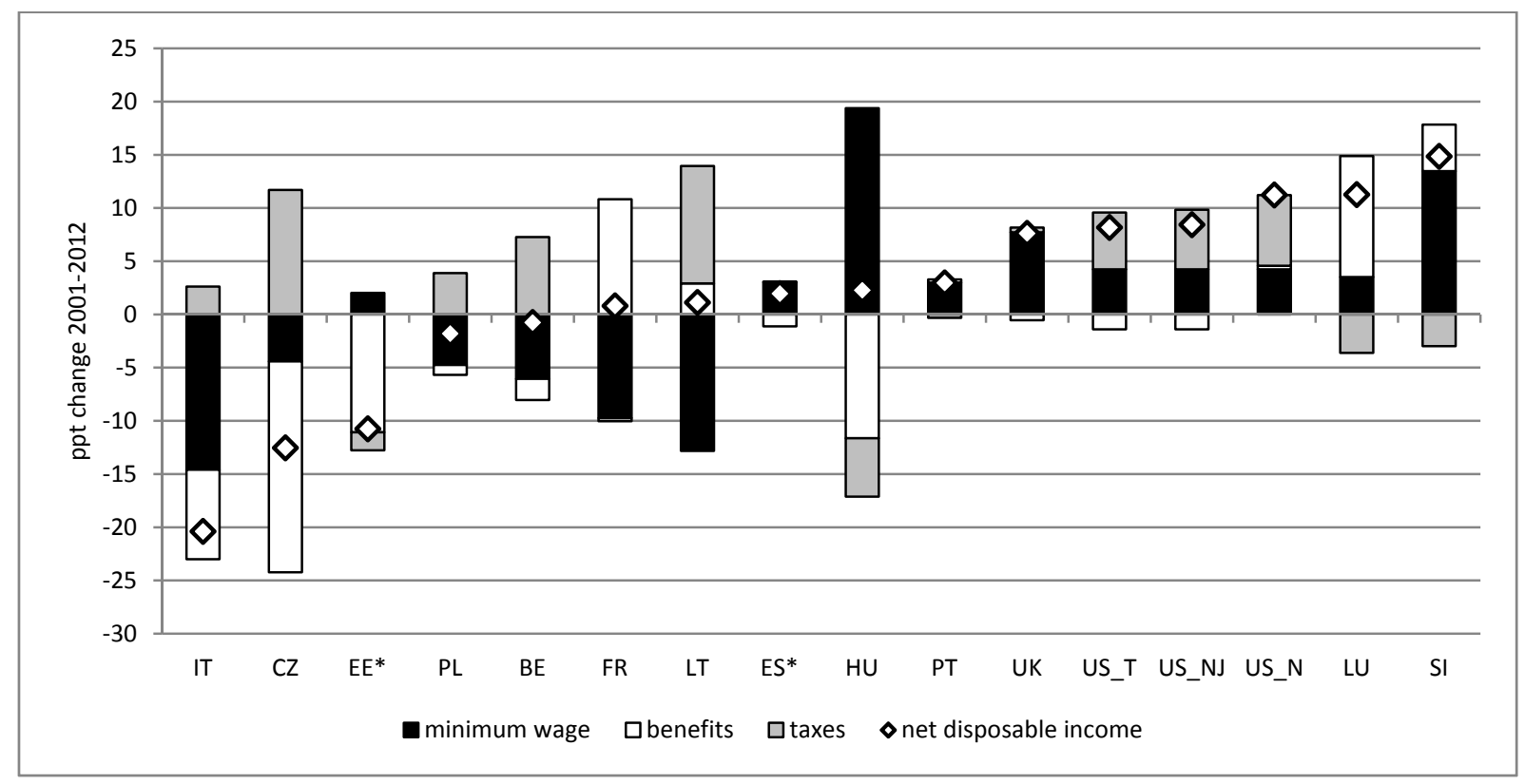

Panel D. Lone parent with 2 children

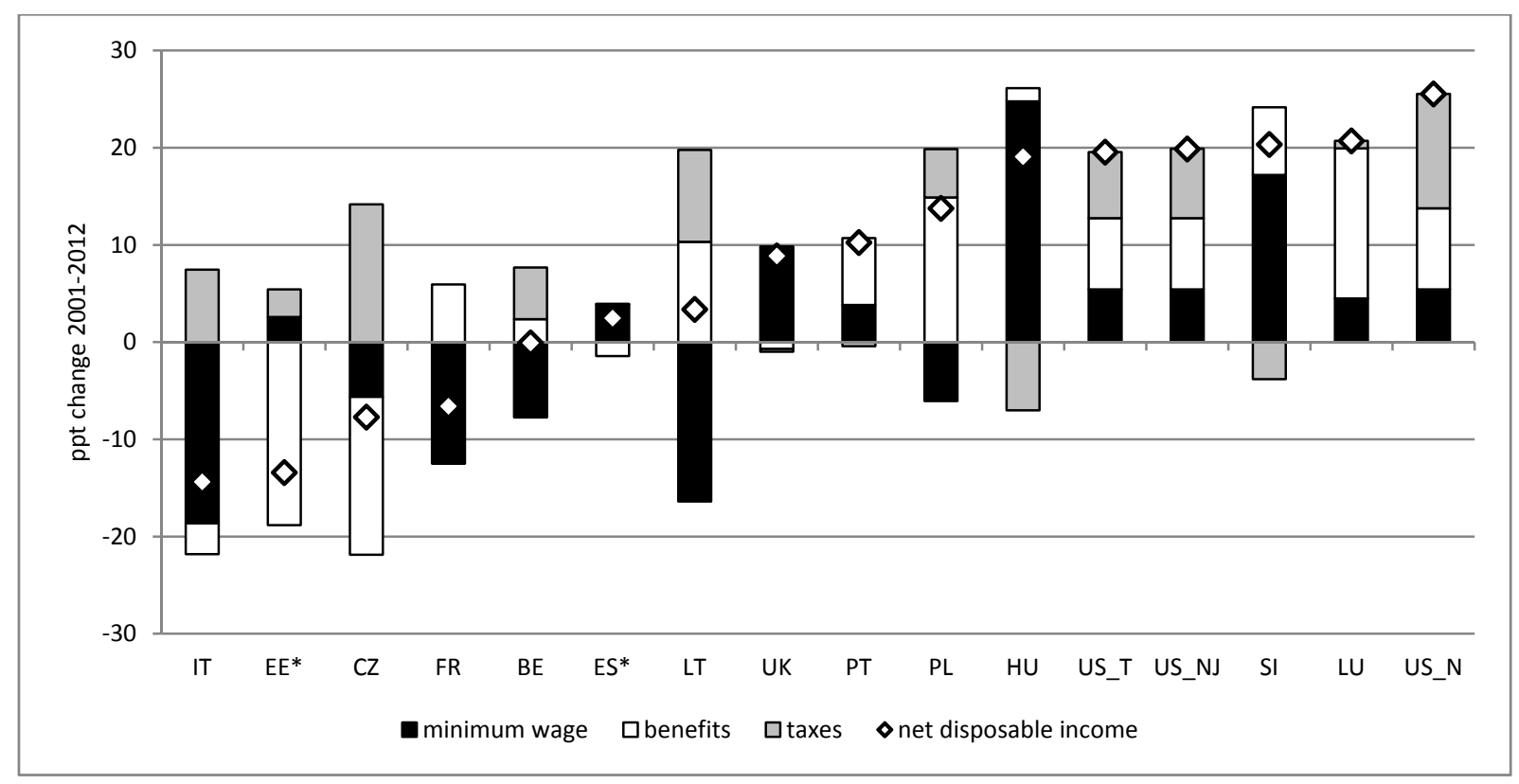

* EE and ES: 2001-2009

Source: CSB MIPI Version 3/2013 (Van Mechelen et al., 2011), Eurostat (2015) 
Finally, trends in housing allowances are quite diverse, especially when taking changes until 2009 into account (see annex). As mentioned already, some caution is needed here. First, housing allowances are a means-tested benefit, and trends in other income components may affect the eligibility to and the level of the housing allowance. Second, housing allowances build on empirical housing costs assumptions. Trends may therefore reflect changes in observed housing costs rather than policy changes. The substantial change in Slovenia was however driven by a policy reform. In late 2001, eligibility to the housing allowance scheme was extended, leading to a substantial increase in the importance of this income component by 2009. In Italy, minimum wage earners were eligible for benefits from the regional housing allowance fund in 2009, but not so in 2001 and 2012.

In sum, figure 4 provides a first indication of the importance of additional income components for the net disposable income of minimum wage earners. Often, other direct income support measures had a more positive impact on the net disposable income than minimum wages did, although there are large differences between the four different household types included in this contribution. In the remainder of this contribution, we focus in somewhat more detail on the impact of the tax system specifically, and on the treatment of the lone parent typical case vs. the couple with two children.

\subsubsection{Is there a trend towards fiscalization?}

As we argued in the section where we elaborated our expectations there are reasons to suspect that the role of tax systems has increased. Figure 4 already showed the importance of declining tax liabilities and social security contributions to the positive development of net disposable incomes. Table 2 shows the specific contribution of changes to the income taxation system. Column 8 shows the percentage point changes in the overall income tax rate for a lone parent with two children. In most countries, income taxes relative to the minimum wage further decreased in the period under analysis, though not by much. The decreases were however quite pronounced in Lithuania, which in 2001 still had a relatively substantial tax liability for this family type, and the Czech Republic and Slovakia, which introduced a substantial child tax credit. In the Czech Republic and Slovakia, this child tax credit effectively replaced part of the child benefit (cf. supra). Also in a number of other countries, such as Estonia and Italy, the importance of fiscal (child) support in the total share of support increased (see columns 6 and 8 of Table 2). Yet there are a number of important exceptions, such as Lithuania and Slovenia, where also more classic benefits were introduced or raised. Similarly, in a substantial number of countries, the importance of fiscal support remained relatively stable (e.g. UK and the US). 
Table 2. Selected indicators of trends in net incomes at minimum wage, lone parent with 2 children, 2001-2012

\begin{tabular}{|c|c|c|c|c|c|c|c|c|c|}
\hline & \multicolumn{2}{|c|}{$\begin{array}{l}\text { minimum wage as } \% \text { of } \\
\text { poverty threshold }\end{array}$} & \multicolumn{2}{|c|}{$\begin{array}{l}\text { Net disposable income as } \\
\% \text { of poverty threshold }\end{array}$} & \multicolumn{2}{|c|}{$\begin{array}{l}\text { Share of child support } \\
\text { through income taxes as } \\
\% \text { of total child effort }\end{array}$} & \multirow{2}{*}{$\begin{array}{c}\Delta \text { income tax } \\
\text { rates 2001- } \\
2012 \\
2001-2012\end{array}$} & \multicolumn{2}{|c|}{$\begin{array}{l}\text { Net support towards lone } \\
\text { parents relative to net } \\
\text { support towards a couple } \\
\text { with two children }\end{array}$} \\
\hline & 2001 & 2012 & 2001 & 2012 & 2001 & 2012 & & 2001 & 2012 \\
\hline $\mathrm{BE}$ & 91 & 83 & 93 & 92 & 0.29 & 0.24 & -1 & 0.24 & 0.66 \\
\hline $\mathrm{CZ}$ & 52 & 46 & 96 & 88 & 0.04 & 0.33 & -28 & 0.72 & 0.83 \\
\hline $\mathrm{EE}^{*}$ & 51 & 49 & 80 & 67 & 0.00 & 0.25 & -10 & 1.33 & n.a. \\
\hline$E S^{*}$ & 51 & 55 & 52 & 54 & 0.00 & 0.00 & 0 & 1.00 & 1.00 \\
\hline FR & 87 & 74 & 102 & 96 & 0.09 & 0.02 & 2 & 0.98 & 0.73 \\
\hline HU & 54 & 79 & 74 & 93 & 0.28 & 0.32 & -3 & 0.56 & 1.06 \\
\hline IT & 103 & 85 & 106 & 91 & 0.20 & 0.33 & -6 & 0.16 & 0.90 \\
\hline LT & 71 & 55 & 66 & 69 & 0.33 & 0.13 & -17 & n.a. & 0.45 \\
\hline LU & 56 & 60 & 66 & 86 & 0.07 & 0.12 & -5 & 0.26 & 0.54 \\
\hline PL & 83 & 77 & 80 & 94 & 0.00 & 0.10 & -1 & n.a. & 3.09 \\
\hline PT & 62 & 66 & 64 & 75 & 0.00 & 0.00 & 0 & 1.00 & 3.81 \\
\hline RO & & 84 & & 87 & 0.02 & 0.16 & 3 & 1.00 & n.a. \\
\hline SI & 54 & 72 & 66 & 87 & 0.16 & 0.04 & 0 & 0.44 & 0.52 \\
\hline SK & & 54 & & 71 & 0.03 & 0.28 & -14 & 0.48 & 0.56 \\
\hline UK & 55 & 65 & 102 & 111 & 0.83 & 0.81 & 10 & 1.02 & 1.01 \\
\hline US_N & 43 & 49 & 67 & 93 & 0.61 & 0.61 & -19 & 0.84 & 1.18 \\
\hline US_NJ & 43 & 49 & 72 & 92 & 0.61 & 0.62 & -9 & 0.86 & 1.12 \\
\hline US_T & 43 & 49 & 69 & 89 & 0.57 & 0.55 & -9 & 0.85 & 1.13 \\
\hline
\end{tabular}

* EE, ES: 2012 n.a.; 2012 data refer to 2009. Average and coefficient of variation exclude countries that are n.a. in 2001 (RO and SK). Net support: difference between gross and net income (i.e. sum of child benefit with housing allowance and social assistance top-up minus social insurance contributions, local taxes and income taxes). Child support through income taxes: income tax liability of a single with children minus income tax liability of a single without children. Child effort: net support to a single with children minus net support to a single. UK: housing allowances not included due to comparability issues.

Source: CSB MIPI Version 3/2013 (Van Mechelen et al., 2011); Eurostat (2015) 


\subsubsection{Are working lone parents deemed more deserving?}

Figure 4 shows trends in net income for both breadwinner couples with children and lone parents. In the period 2001-2012, lone parents fared better in all countries included in Figure 4, with the exception of France (and Estonia in the period 2001-2009. This is confirmed when we compare the net support towards lone parents with the support for breadwinner couples with children (columns 9 and 10 of Table 2). In all countries but France, this ratio increased from 2001 to 2012, and in some countries even quite substantially. The drivers of these increases are diverse. For instance, Belgium and Poland introduced specific categorical child benefit supplements to lone parent families. Other countries, such as Luxembourg, implemented a tax benefit for lone parents. Elsewhere, the increase is the consequence of the family types becoming eligible for a social assistance top-up. However, the activity requirements in some social assistance schemes make breadwinner couples ineligible, a reservation that does not apply to a working lone parent. Portugal is a prime example in this case. Note that in France, breadwinner couples remained eligible for a social assistance top-up. In fact, the exceptional finding that relatively more support was directed towards breadwinner couples than to lone parent families in this country, is driven by the higher social assistance top-up a couple with children receives. The general pattern however is clearly different and consistent with our hypothesis. 


\section{Conclusion}

This contribution has explored trends in the net disposable incomes of minimum wage earners in the EU and in three US states for reference.

This is relevant for a number of reasons. First, the wages of less skilled workers are believed to be under pressure in the richest countries. Intensifying competition from countries where less skilled labour comes much cheaper is one major perceived driver. Skilled-biased technological change is another because it intensifies competition for tasks that are not (yet) taken over by machines. Within the EU enlargement may have exerted substantial added pressure. Workers and firms from countries with much lower wages and excess labour supply gained full access to the EU Single Market in a relatively short period of time around 2004 and 2007. All this gives ground to suspect that minimum wages came under pressure in the countries where these were highest at the start of our observation period, the early 2000s.

We do find some downward convergence of minimum wages within the EU. However, the decrease in variation is only very limited in relative terms, and is not coupled to a general decrease in minimum wages. Rather, countries with initially quite low minimum wages issued substantial increases, whereas the minimum wages in the more generous countries lost ground relative to average living standards.

From the outset, we did not expect net incomes to necessarily follow these trends in minimum wages. Concerns with 'making work pay' and in-work poverty grew increasingly prominent during the 2000s. We hypothesized that this may have motivated governments to impact on net incomes through additional income support measures, even if they saw limited scope for minimum wage increases. We do find that governments counteracted (or at least softened) decreases in relative minimum wages through direct income support measures. Most prevalent among these were a substantial decline in income tax liabilities, especially for single households that were still facing relatively substantial tax burdens at the start of the observation period. In many countries, the importance of child support through the tax system in the overall net income support seems to have increased. This is consistent with claims that a trend is unfolding towards a fiscalization of income support policies. Finally, we hypothesized that the strongest efforts were aimed at working lone parents. We assumed so because low skilled one parents face the highest risk of entrapment in longterm benefit dependence unless the transition to a low-skilled jobs brings a significant income gain. At the same time they and their children face the highest risk of remaining poor if they have to make ends meet on low pay. We do find indications that governments stepped up efforts to offer income support for low earnings households and that this happened even more for lone parents as compared to single persons or breadwinner couples.

In a way this is relatively hopeful. Yet the fact of the matter remains that in-work poverty persists even in countries that have taken the most substantial additional efforts to support households on low earnings. It is worth stressing again that in most EU countries a majority of children growing up in financial poverty live in households that mainly rely on earnings. For many of them this is a long-term affliction when parents (or more often the sole parent) have limited opportunities for upward pay mobility. Thus for the rhetoric of 'making work pay' and 'a job is the best protection against poverty' to become a reality there is still a long way to go in many countries. The question is whether 
governments will have enough zeal and resources to stem what seems to be an inevitable tide towards fewer decent jobs for the least skilled and yet ever greater competition for these jobs.

\section{Annex}

Table 3a. Income components as \% of gross minimum wage, single

\begin{tabular}{|c|c|c|c|c|c|c|c|c|c|c|c|c|}
\hline & \multicolumn{3}{|c|}{ income tax } & \multicolumn{3}{|c|}{$\begin{array}{l}\text { social insurance } \\
\text { contributions }\end{array}$} & \multicolumn{3}{|c|}{$\begin{array}{l}\text { social } \\
\text { assistance }\end{array}$} & \multicolumn{3}{|c|}{$\begin{array}{l}\text { housing } \\
\text { allowance }\end{array}$} \\
\hline & 2001 & 2009 & 2012 & 2001 & 2009 & 2012 & 2001 & 2009 & 2012 & 2001 & 2009 & 2012 \\
\hline $\mathrm{BE}$ & -17 & -17 & -17 & -7 & -2 & -2 & 0 & 0 & 0 & 0 & 0 & 0 \\
\hline$C Z$ & -4 & 0 & 0 & -13 & -11 & -11 & 0 & 0 & 0 & 13 & 12 & 19 \\
\hline EE & -10 & -9 & -10 & 0 & -4 & -5 & 0 & 0 & 0 & 0 & 0 & 0 \\
\hline ES & 0 & 0 & & -6 & -7 & & 0 & 0 & & 0 & 0 & \\
\hline FR & -1 & 3 & -1 & -21 & -22 & -22 & 0 & 1 & 1 & 4 & 4 & 3 \\
\hline $\mathrm{HU}$ & -23 & -2 & -16 & -11 & -17 & -19 & 0 & 0 & 3 & 0 & 0 & 0 \\
\hline IT & -12 & -10 & -11 & -9 & -9 & -9 & 0 & 0 & 0 & 0 & 9 & 0 \\
\hline LT & -24 & -6 & -6 & -3 & -9 & -9 & 0 & 0 & 0 & 0 & 0 & 0 \\
\hline LU & -2 & -1 & -2 & -11 & -12 & -12 & 0 & 0 & 2 & 0 & 0 & 0 \\
\hline PL & -1 & -4 & -4 & -25 & -21 & -21 & 0 & 0 & 0 & 6 & 0 & 3 \\
\hline PT & 0 & 0 & 0 & -11 & -11 & -11 & 0 & 0 & 0 & 0 & 0 & 0 \\
\hline RO & 0 & -7 & -8 & -20 & -17 & -17 & 0 & 0 & 0 & 0 & 0 & 0 \\
\hline SI & -8 & -1 & -1 & -22 & -22 & -22 & 0 & 0 & 0 & 0 & 0 & 9 \\
\hline SK & -2 & 0 & 1 & -13 & -13 & -13 & 0 & 0 & 0 & 13 & 0 & 0 \\
\hline UK & -4 & 3 & 2 & -3 & -5 & -4 & 0 & 0 & 0 & 0 & 0 & 0 \\
\hline US_N & -2 & -2 & -5 & -8 & -8 & -6 & 0 & 0 & 0 & 0 & 0 & 0 \\
\hline US_NJ & -2 & -2 & -5 & -8 & -8 & -6 & 1 & 6 & 6 & 0 & 0 & 0 \\
\hline US_T & -2 & -1 & -4 & -8 & -8 & -6 & 0 & 1 & 0 & 0 & 0 & 0 \\
\hline
\end{tabular}

Table $3 \mathrm{~b}$. Income components as $\%$ of gross minimum wage, couple

\begin{tabular}{lllllllllllll}
\hline & \multicolumn{3}{l}{ income tax } & \multicolumn{3}{c}{$\begin{array}{l}\text { Social insurance } \\
\text { contributions }\end{array}$} & \multicolumn{3}{c}{$\begin{array}{l}\text { social } \\
\text { assistance }\end{array}$} \\
\hline & 2001 & 2009 & 2012 & 2001 & 2009 & 2012 & 2001 & 2009 & 2012 & 2001 & 2009 & 2012 \\
BE & -8 & -4 & -4 & -7 & -2 & -2 & 0 & 0 & 0 & 0 & 0 & 0 \\
CZ & 0 & 0 & 0 & -26 & -25 & -25 & 38 & 28 & 25 & 13 & 12 & 23 \\
EE & 0 & 0 & & 0 & -4 & & 0 & 0 & & 0 & 0 & \\
ES & 0 & 0 & & -6 & -7 & & 0 & 0 & & 0 & 0 & \\
FR & 1 & -1 & -1 & -21 & -22 & -22 & 0 & 14 & 14 & 11 & 11 & 11 \\
HU & -23 & -2 & -16 & -11 & -17 & -19 & 32 & 0 & 4 & 4 & 6 & 0 \\
IT & -7 & -5 & -6 & -9 & -9 & -9 & 0 & 0 & 0 & 0 & 14 & 0 \\
LT & -24 & -6 & -6 & -3 & -9 & -9 & 0 & 0 & 0 & 0 & 0 & 0 \\
LU & 0 & 0 & -1 & -11 & -12 & -13 & 37 & 45 & 48 & 0 & 0 & 0 \\
PL & -1 & -4 & -4 & -25 & -21 & -21 & 0 & 0 & 0 & 8 & 2 & 9 \\
PT & 0 & 0 & 0 & -11 & -11 & -11 & 0 & 0 & 0 & 0 & 0 & 0 \\
RO & 0 & -4 & -5 & -20 & -17 & -17 & 0 & 0 & 0 & 0 & 0 & 0 \\
SI & -4 & 0 & 0 & -22 & -22 & -22 & 0 & 0 & 0 & 0 & 17 & 13 \\
SK & 0 & 0 & 1 & -13 & -13 & -13 & 25 & 0 & 15 & 22 & 0 & 0 \\
UK & -4 & 21 & 19 & -3 & -5 & -4 & 0 & 0 & 0 & 0 & 0 & 0 \\
US_N & 0 & 5 & 2 & -8 & -8 & -6 & 7 & 8 & 2 & 0 & 0 & 0 \\
US_NJ & 0 & 4 & 1 & -8 & -8 & -6 & 13 & 19 & 6 & 0 & 0 & 0 \\
US_T & 0 & 5 & 2 & -8 & -8 & -6 & 12 & 9 & 4 & 0 & 0 & 0 \\
\hline
\end{tabular}


Table3c. Income components as \% of gross minimum wage, couple with two children

\begin{tabular}{|c|c|c|c|c|c|c|c|c|c|c|c|c|c|c|c|}
\hline & \multicolumn{3}{|c|}{ income tax } & \multicolumn{3}{|c|}{$\begin{array}{l}\text { social insurance } \\
\text { contributions }\end{array}$} & \multicolumn{3}{|c|}{$\begin{array}{l}\text { child } \\
\text { benefit }\end{array}$} & \multicolumn{3}{|c|}{$\begin{array}{l}\text { social } \\
\text { assistance }\end{array}$} & \multicolumn{3}{|c|}{$\begin{array}{l}\text { housing } \\
\text { allowance }\end{array}$} \\
\hline & 200 & 200 & 201 & 200 & 200 & 201 & 200 & 200 & 201 & 200 & 200 & 201 & 200 & 200 & 201 \\
\hline & 1 & 9 & 2 & 1 & 9 & 2 & 1 & 9 & 2 & 1 & 9 & 2 & 1 & 9 & 2 \\
\hline BE & -3 & 2 & 3 & -7 & -2 & -2 & 20 & 19 & 19 & 0 & 0 & 0 & 0 & 0 & 0 \\
\hline$C Z$ & 0 & 22 & 28 & -26 & -25 & -25 & 53 & 40 & 15 & 70 & 43 & 79 & 22 & 14 & 14 \\
\hline EE & 0 & 0 & & 0 & -4 & & 28 & 14 & & 14 & 0 & & 0 & 0 & \\
\hline ES & 0 & 0 & & -6 & -7 & & 11 & 8 & & 0 & 0 & & 0 & 0 & \\
\hline $\mathrm{FR}$ & 2 & 0 & 0 & -21 & -22 & -22 & 13 & 14 & 12 & 0 & 24 & 24 & 24 & 25 & 25 \\
\hline $\mathrm{HU}$ & -3 & -2 & 0 & -11 & -17 & -19 & 44 & 37 & 29 & 32 & 7 & 7 & 4 & 11 & 0 \\
\hline IT & -2 & 0 & 0 & -9 & -9 & -9 & 28 & 23 & 22 & 0 & 0 & 0 & 0 & 20 & 0 \\
\hline LT & -24 & -1 & -1 & -3 & -9 & -9 & 0 & 13 & 13 & 47 & 64 & 55 & 0 & 0 & 0 \\
\hline LU & 0 & -1 & -3 & -11 & -12 & -14 & 32 & 39 & 37 & 52 & 61 & 65 & 0 & 0 & 0 \\
\hline PL & -1 & 0 & 0 & -25 & -21 & -21 & 11 & 10 & 13 & 0 & 13 & 0 & 19 & 9 & 17 \\
\hline PT & 0 & 0 & 0 & -11 & -11 & -11 & 15 & 19 & 15 & 0 & 0 & 0 & 0 & 0 & 0 \\
\hline RO & 0 & 0 & -1 & -20 & -17 & -17 & 22 & 24 & 19 & 0 & 0 & 0 & 0 & 0 & 0 \\
\hline SI & 0 & 0 & 0 & -22 & -22 & -22 & 44 & 39 & 32 & 12 & 9 & 12 & 15 & 24 & 19 \\
\hline SK & 0 & 13 & 14 & -13 & -13 & -13 & 38 & 14 & 14 & 52 & 0 & 43 & 30 & 0 & 0 \\
\hline UK & 81 & 69 & 70 & -3 & -5 & -4 & 20 & 17 & 16 & 0 & 0 & 0 & 0 & 0 & 0 \\
\hline US_N & 38 & 54 & 50 & -8 & -8 & -6 & 0 & 0 & 0 & 35 & 37 & 32 & 0 & 0 & 0 \\
\hline US_N & 44 & 58 & 53 & -8 & -8 & -6 & 0 & 0 & 0 & 41 & 44 & 32 & 0 & 0 & 0 \\
\hline US T & 38 & 51 & 47 & -8 & -8 & -6 & 0 & 0 & 0 & 41 & 37 & 32 & 0 & 0 & 0 \\
\hline
\end{tabular}

Table3d. Income components as \% of gross minimum wage, lone parent with two children

\begin{tabular}{|c|c|c|c|c|c|c|c|c|c|c|c|c|c|c|c|}
\hline & \multicolumn{3}{|c|}{ income tax } & \multicolumn{3}{|c|}{$\begin{array}{l}\text { social insurance } \\
\text { contributions }\end{array}$} & \multicolumn{3}{|c|}{$\begin{array}{l}\text { child } \\
\text { benefit }\end{array}$} & \multicolumn{3}{|c|}{$\begin{array}{l}\text { social } \\
\text { assistance }\end{array}$} & \multicolumn{3}{|c|}{$\begin{array}{l}\text { housing } \\
\text { allowance }\end{array}$} \\
\hline & 200 & 200 & 201 & 200 & 200 & 201 & 200 & 200 & 201 & 200 & 200 & 201 & 200 & 200 & 201 \\
\hline & 1 & 9 & 2 & 1 & 9 & 2 & 1 & 9 & 2 & 1 & 9 & 2 & 1 & 9 & 2 \\
\hline BE & -9 & -9 & -9 & -7 & -2 & -2 & 20 & 25 & 25 & 0 & 0 & 0 & 0 & 0 & 0 \\
\hline$C Z$ & 0 & 22 & 28 & -13 & -11 & -11 & 53 & 34 & 15 & 24 & 20 & 41 & 22 & 14 & 20 \\
\hline EE & -10 & 0 & & 0 & -4 & & 66 & 28 & & 0 & 0 & & 0 & 0 & \\
\hline ES & 0 & 0 & & -6 & -7 & & 11 & 8 & & 0 & 0 & & 0 & 0 & \\
\hline FR & 2 & 0 & 0 & -21 & -22 & -22 & 13 & 14 & 12 & 0 & 14 & 14 & 24 & 25 & 25 \\
\hline $\mathrm{HU}$ & -3 & -2 & 0 & -11 & -17 & -19 & 47 & 41 & 32 & 0 & 0 & 5 & 4 & 8 & 0 \\
\hline IT & -7 & 0 & -1 & -9 & -9 & -9 & 21 & 23 & 22 & 0 & 0 & 0 & 0 & 20 & 0 \\
\hline LT & -18 & -1 & -1 & -3 & -9 & -9 & 0 & 13 & 13 & 13 & 25 & 23 & 0 & 0 & 0 \\
\hline LU & 0 & 5 & 5 & -11 & -12 & -13 & 32 & 39 & 37 & 0 & 16 & 18 & 0 & 0 & 0 \\
\hline PL & -1 & 0 & 0 & -25 & -21 & -21 & 11 & 37 & 36 & 0 & 0 & 0 & 13 & 3 & 9 \\
\hline PT & 0 & 0 & 0 & -11 & -11 & -11 & 15 & 23 & 17 & 0 & 13 & 7 & 0 & 0 & 0 \\
\hline RO & 0 & -1 & -3 & -20 & -17 & -17 & 22 & 27 & 25 & 0 & 0 & 0 & 0 & 0 & 0 \\
\hline SI & 0 & 0 & 0 & -22 & -22 & -22 & 44 & 43 & 27 & 0 & 0 & 0 & 0 & 21 & 16 \\
\hline SK & 0 & 13 & 14 & -13 & -13 & -13 & 38 & 14 & 14 & 6 & 0 & 18 & 20 & 0 & 0 \\
\hline UK & 81 & 69 & 70 & -3 & -5 & -4 & 20 & 17 & 16 & 0 & 0 & 0 & 0 & 0 & 0 \\
\hline US_N & 38 & 51 & 57 & -8 & -8 & -6 & 0 & 0 & 0 & 25 & 25 & 39 & 0 & 0 & 0 \\
\hline US_N & 44 & 56 & 53 & -8 & -8 & -6 & 0 & 0 & 0 & 30 & 32 & 42 & 0 & 0 & 0 \\
\hline US_T & 38 & 48 & 47 & -8 & -8 & -6 & 0 & 0 & 0 & 30 & 25 & 42 & 0 & 0 & 0 \\
\hline
\end{tabular}

Source: CSB MIPI Version 3/2013 (Van Mechelen et al., 2011) 


\section{References}

Adema, W. (1997). What do countries really spend on social policies? a comparative note (OECD Economic Studies). Paris: OECD.

Annesley, C. (2007). Lisbon and social Europe: towards a European 'adult worker model' welfare system. Journal of European Social Policy, 17(3), 195-205. doi: 10.1177/0958928707078363

Bradshaw, J., \& Hatland, A. (2006). Introduction. In J. Bradshaw \& A. Hatland (Eds.), Social Policy, Employment And Family Change In Comparative Perspective. Cheltenham: Edward Elgar.

Cantillon, B., Collado, D., \& Van Mechelen, N. (forthcoming). The end of decent incomes for the poor? The fatal link between minimum wages and social benefits in world's most developed welfare states. (CSB Working Papers). Antwerp: Herman Deleeck Centre for Social Policy.

Cantillon, B., \& Van Mechelen, N. (2014). Cracks in a policy paradigm - poverty reduction and social security: the case of Belgium. International Review of Sociology, 24(2), 270-290. doi: $10.1080 / 03906701.2014 .933026$

Cantillon, B., \& Vandenbroucke, F. (2014). Reconciling work and poverty reduction. How successful are European welfare states? Oxford: Oxford University Press.

Corluy, V., \& Vandenbroucke, F. (2014). Indiviudal employment, household employment, and risk of poverty in the European Union. A decomposition analysis. In B. Cantillon \& F. Vandenbroucke (Eds.), Reconciling work and poverty reduction (pp. 94-130). Oxford: Oxford university press.

Daly, M. (2011). What Adult Worker Model? A Critical Look at Recent Social Policy Reform in Europe from a Gender and Family Perspective. Social Politics: International Studies in Gender, State \& Society, 18(1), 1-23. doi: 10.1093/sp/jxr002

Dolado, J., Felgueroso, F., \& Jimeno, J. (2000). The role of the minimum wage in the welfare state: an appaisal (IZA Discussion paper). Bonn: IZA.

Draxler, J., \& Van Vliet, O. (2010). European Social Model: No Convergence from the East. Journal of European Integration, 32(1), 115-135. doi: 10.1080/07036330903375230

Erhel, C., \& Zajdela, H. (2004). The Dynamics of Social and Labour Market Policies in France and the United Kingdom: Between Path Dependence and Convergence. Journal of European Social Policy, 14(2), 125-142. doi: 10.1177/0958928704042004

Commission Recommendation of 3 October 2008 on the active inclusion of people excluded from the labour market 2008/867/EC C.F.R. (2008a).

Commission Recommendation of 3 October 2008 on the active inclusion of people excluded from the labour market (notified under document number C(2008) 5737), 2008/867/EC C.F.R. (2008b).

European Commission. (2011). Employment and social developments in Europe). Luxembourg: Publications office of the European Communities.

Eurostat. (2015). Statistics by theme. Retrieved May 2015 http://epp.eurostat.ec.europa.eu/portal/page/portal/statistics/themes

Ferrarini, T., Nelson, K., \& Höög, H. (2013). From universalism to selectivity: old wine in new bottles for child benefits in Europe en other countries. In I. Marx \& K. Nelson (Eds.), Minimum income protection in flux (pp. 137-160). Basingstoke: Palgrave Macmillan.

Freeman, R. (1996). The minimum wage as a redistributive tool. Economic Journal(106).

Gaffney, D. (2014). Are in-work benefits in the UK a magnet for EU migrants? Retrieved from http://touchstoneblog.org.uk/2014/12/are-in-work-benefits-in-the-uk-a-magnet-for-eumigrants/

Immervoll, H. (2007). Minimum wages, minimum labour costs and the tax treatment of low-wage employment (IZA Discussion paper series Discussion Paper no. 2555). Bonn: IZA.

Immervoll, H. (2012). Reforming the benefit system to make work pay: options and priorities in a weak labour market (IZA policy paper). IZA.

International Labour Organization. (2008). Global Wage Report 2008 / 09: Minimum wages and collective bargaining - Towards policy coherence. Geneva: International labour organization. 
Jensen, C. (2010). Catching up by transition: globalization as a generator of convergence in social spending. Journal of European public policy, 18(1), 106-121.

Kenworthy, L. (forthcoming). Do Employment-Conditional Earnings Subsidies Work? (Improve policy paper). Herman Deleeck Centre for Social Policy.

Knijn, T., Martin, C., \& Millar, J. (2007). Activation as a Common Framework for Social Policies towards Lone Parents. Social Policy \& Administration, 41(6), 638-652. doi: 10.1111/j.14679515.2007.00576.x

Kvist, J. (2004). Does EU enlargement start a race to the bottom? Strategic interaction among EU member states in social policy. Journal of European Social Policy, 14, 301.

Malmberg, J. (2010). The impact of the ECJ judgments on Viking, Laval, Rüffert and Luxembourg on the practice of collective bargaining and the effectiveness of social action (Employment and social affairs). DG for internal policies, .

Marx, I., Horemans, J., Marchal, S., Van Rie, T., \& Corluy, V. (2013). Towards a better marriage between job growth and poverty reduction (GINI policy paper). AIAS.

Marx, I., Marchal, S., \& Nolan, B. (2013). Mind the gap: net incomes of minimum wage workers in the EU and the US. In I. Marx \& K. Nelson (Eds.), Minimum income protection in flux (pp. 54-80). Houndmills: Palgrave.

Marx, I., \& Nolan, B. (2014). In-work poverty. In B. Cantillon \& F. Vandenbroucke (Eds.), Reconciling work and poverty reduction (pp. 133-156). Oxford: Oxford University Press.

Marx, I., Vanhille, J., \& Verbist, G. (2012). Combating in-work poverty in continental Europe: the potential impact of higher minimum wages and targeted tax relief. Journal of Social Policy, 41(1), 19-41. doi: 10.1017/s0047279411000341

McBride, S., \& Williams, R. A. (2001). Globalization, the Restructuring of Labour Markets and Policy Convergence: The OECD 'Jobs Strategy'. Global social policy, 1(3), 281-309. doi: $10.1177 / 146801810100100302$

Montanari, I., Nelson, K., \& Palme, J. (2008). TOWARDS A EUROPEAN SOCIAL MODEL? European Societies, 10(5), 787-810. doi: 10.1080/13668800801912543

OECD. (2005). Extending opportunities: how active social policy can benefit us all. Paris: OECD.

OECD. (2009). Employment outlook: tackling the jobs crisis. Paris: OECD.

OECD. (2015). OECD Stat.Extracts. $\quad$ Retrieved May 2015 http://stats.oecd.org/index.aspx?queryid=35253\#

Paetzold, J. (2012). the convergence of welfare state indicators in Europe: evidence from panel data (Working papers in economics and finance). University of Salzburg.

Paetzold, J., \& Van Vliet, O. (2012). convergence without hard criteria: does EU soft law affect domestic unemployment protection schemes? (Working papers in Economics and finance). University of Salzburg.

Rodrigues, C. F. (2012). Minimum Income in Portugal: Changing the Rules in Times of Crisis WP 05/2012/DE/CEMAPRE). School of Economics and Management, technical university of Lisbon.

Ryckx, F., \& Kampelmann, S. (2012). Who earns minimum wages in Europe? New evidence based on household surveys (Report 124). Brussels: European trade union institute.

Scharpf, F. W. (2002). The European Social Model: Coping with the Challenges of Diversity. Journal of common market studies, 40(4), 645-670.

Sinn, H. W. (2002). EU enlargement and the future of the welfare state. Scottish Journal of Political economy, 49(1), 104-115.

Skedinger, P. (2010). Employment protection legislation: evolution, effects, winners and losers. Cheltenham: Edward Elgar.

Skevik, A. (2006). Working their way out of poverty? Lone mothers in policies and labour markets. In J. Bradshaw \& A. Hatland (Eds.), Social Policy, Employment And Family Change In Comparative Perspective. Cheltenham: Edward Elgar. 
Van Lancker, W., Ghysels, J., \& Cantillon, B. (forthcoming). The impact of child benefits on single mother poverty: exploring the role of targeting in 15 European countries. International Journal of Social Welfare.

Van Lancker, W., \& Van Mechelen, N. (forthcoming). Universalism under siege? Exploring the association between targeting, child benefits and child poverty across 26 countries. Social Science Research.

Van Mechelen, N., \& Bradshaw, J. (2013). Child Poverty as a Government Priority: Child Benefit Packages for Working Families, 1992-2009. In I. Marx \& K. Nelson (Eds.), Minimum Income Protection in Flux (pp. 81-107): Palgrave Macmillan.

Van Mechelen, N., \& Marchal, S. (2013). Trends and convergence of Europe's minimum income schemes (Improve working papers 13/11). Antwerp: Herman Deleeck Centre for Social Policy.

Van Mechelen, N., Marchal, S., Goedemé, T., Marx, I., \& Cantillon, B. (2011). The CSB-Minimum Income Protection Indicators dataset (CSB-MIPI) (CSB Working Paper Series CSB WP 11/05). Antwerp: Herman Deleeck Centre for Social Policy, University of Antwerp.

Van Rie, T., \& Marx, I. (2012). The EU at work? The European employment strategy from crisis to crisis. Journal of common market studies, 50(2), 1-28. doi: 10.1111/j.1468-5965.2011.02206.x

Van Vliet, O., Caminada, K., \& Goudswaard, K. (2010). Patterns of welfare state indicators in the EU: is there convergence. Journal of common market studies, 48(3), 529-556.

Vandenbroucke, F., \& Diris, R. (2014). Mapping at-risk-of-poverty rates, Household Employment and Social Spending. In B. Cantillon \& F. Vandenbroucke (Eds.), Reconciling work and poverty reduction: how successful are European welfare states? (pp. 1-59). Oxford: Oxford University Press.

Vandenbroucke, F., \& Vinck, J. (2013). Child Poverty Risks in Belgium, Wallonia, Flanders: Accounting for a Worrying Performance. In P. Maystadt, E. Cantillon, L. Denayer, P. Pestieau, B. Van der Linden \& M. Cattelain (Eds.), Le modèle social belge : quel avenir ? Charleroi: Presses interuniversitaires de Charleroi.

Verschueren, H. (2015). Preventing 'benefit tourism' in the EU: a narrow or broad interpretation of the possibilities offered by the ECJ in DANO? Common Market Law Review, 52(2), 363-390.

Weishaupt, T. (2011). From the Manpower Revolution to the Activation Paradigm: Explaining Institutional Continuity and Change in an Integrating Europe. Amsterdam: Amsterdam University Press. 